\title{
Biosorption potential of dead and living Arthrobacter viscosus biomass in the removal of $\mathrm{Cr}(\mathrm{VI})$ : Batch and column studies
}

\author{
Raluca Maria Hlihor ${ }^{a}$, Hugo Figueiredo ${ }^{b}$, Teresa Tavares ${ }^{b}$, \\ Maria Gaurilescu ${ }^{a, *}$ \\ a Gheorghe Asachi" Technical University of Iasi, Faculty of Chemical Engineering and Environmental Protection, \\ Department of Environmental Engineering and Management, 73 Prof.dr.docent D. Mangeron Street, 700050, Iasi, \\ Romania \\ $\mathrm{b}$ IBB-Institute for Biotechnology and Bioengineering, Centre of Biological Engineering, University of Minho, Campus \\ de Gualtar, 4710-057 Braga, Portugal
}

\section{A R T I C L E I N F O}

\section{Article history:}

Received 5 January 2016

Received in revised form 29 May

2016

Accepted 8 June 2016

Available online 16 June 2016

\section{Keywords:}

$\mathrm{Cr}$ (VI) removal/reduction

Biosorption

A. viscosus

Bacterial biofilm

Aqueous solution

\begin{abstract}
A B S T R A C T
Batch experiments were conducted with dead and living Arthrobacter viscosus biomass for $\mathrm{Cr}(\mathrm{VI})$ removal from aqueous solution. Both dead and living cells successfully reduced $\mathrm{Cr}(\mathrm{VI})$ to $\mathrm{Cr}$ (III) from aqueous solution in highly acidic $\mathrm{pH}$ (pH 1 and 2) with an efficiency of $100 \%$ for aqueous solutions having the initial concentrations of $\mathrm{Cr}$ (VI) lower than $100 \mathrm{mg} / \mathrm{L}$. Langmuir isotherm and kinetic models based on reduction could simulate chromium removal at 5 and $8 \mathrm{~g} / \mathrm{L}$ biosorbent dosages and in highly acidic $\mathrm{pH}$ conditions ( $\mathrm{pH} 1-2)$. Further, the potential use of the A. viscosus biomass was examined in an open system, where $\mathrm{Cr}(\mathrm{VI})$ removal from aqueous solution was performed by a bacterial biofilm supported on a new type of polyethylene supports. The experiment showed a favorable uptake of chromium ions bound to the biomass, of $20.37 \mathrm{mg} / \mathrm{g}$, with high potential for scaling up. This study showed that the reduction of toxic $\mathrm{Cr}$ (VI) to the less toxic $\mathrm{Cr}$ (III) by A. viscosus, in batch and continuous modes is an efficient and promising technique for wastewaters polluted with chromium.

(c) 2016 Institution of Chemical Engineers. Published by Elsevier B.V. All rights reserved.
\end{abstract}

\section{Introduction}

Chromium can be found in natural deposits as ores and also in several other natural materials in its compound forms. A variety of anthropogenic sources release chromium in the environment (plating industry, textile dyeing, cement, leather tanning, wood preservation etc.). These sources could generate severe environmental and public health threats. In the natural environment only hexavalent $(\mathrm{Cr}(\mathrm{VI}))$ and trivalent (Cr(III)) chromium are stable forms, although chromium may occur in several different oxidation states ranging from -2 to +6 . The two stable oxidation states of chromium may present different behaviors in terms of toxicity and mobility.
$\mathrm{Cr}$ (III) is relatively insoluble in aqueous systems and exhibits little or no toxicity, being an essential trace nutrient for humans. In contrast, $\mathrm{Cr}(\mathrm{VI})$ usually occurs as highly soluble and highly toxic chromate anions $\left(\mathrm{CrO}_{4}{ }^{2-}\right.$ and $\left.\mathrm{Cr}_{2} \mathrm{O}_{7}{ }^{2-}\right)$, which are suspected as carcinogens and mutagens (Park et al., 2004; Prabhakaran et al., 2009). The aqueous effluents may contain various concentrations of $\mathrm{Cr}(\mathrm{VI})$, depending on their source. For example, the concentration of $\mathrm{Cr}(\mathrm{VI})$ in chromium plating effluents ranges between $15 \mathrm{mg} / \mathrm{L}$ and $300 \mathrm{mg} / \mathrm{L}$, occasionally exceeding $960 \mathrm{mg} / \mathrm{L}$. At an extreme level, effluents from tannery factories have been reported to contain $1300-2500 \mathrm{mg} / \mathrm{L}$ of $\mathrm{Cr}(\mathrm{VI})$ (Liu et al., 2006). USEPA and the European Union regulated the discharge of chromium(VI) to surface water to

\footnotetext{
* Corresponding author. Tel.: +40 232 278680x2137; fax: +40 232271311.

E-mail addresses: mgav@tuiasi.ro,mgav_ro@yahoo.com (M. Gavrilescu). http://dx.doi.org/10.1016/j.psep.2016.06.016

0957-5820/@ 2016 Institution of Chemical Engineers. Published by Elsevier B.V. All rights reserved.
} 
below $0.05 \mathrm{mg} / \mathrm{L}$, while total chromium, including $\mathrm{Cr}$ (III), $\mathrm{Cr}$ (VI) and the other forms, is regulated to below $2 \mathrm{mg} / \mathrm{L}$ (Baral and Engelken, 2002; Park et al., 2008).

The removal of chromium from contaminated effluents by physical, chemical and electrochemical methods generally involves high energy inputs and costs, large quantities of chemical reagents or difficulties in removing the by-products or secondary waste generated during the process. As a part of environmental biotechnology, biosorption process has been extensively studied for the removal of heavy metals using various biomass (microbial, algae, agricultural or industrial waste) (Altaher et al., 2015; Flouty, 2015; Ghosh et al., 2015; Hlihor et al., 2015; Jaafarzadeh et al., 2014; Liu et al., 2016; Murugavelh and Mohanty, 2014; Murphy et al., 2008; Paduraru et al., 2015; Parvathi and Nagendran, 2007; Ungureanu et al., 2015). It has been demonstrated that these biosorbents can be used successfully for metal removal and wastewater detoxification in a very competitive and cost efficient manner (Chojnacka, 2010; Ebrahimi et al., 2015; Gavrilescu et al., 2015; Hlihor et al., 2013, 2014; Liu et al., 2011; Lopez-Nuñez et al., 2014; Rosca et al., 2015; Vijayaraghavan and Yun, 2008).

In this work the non-pathogenic Arthrobacter viscosus, a gram-positive aerobic bacterium from the family of Micrococcaceae, order of Actinomycetales, which is a good exopolysaccharide producer was chosen as biosorbent due to its high potential in bioremediation (Figueiredo et al., 2010; Fonseca et al., 2012; Quintelas et al., 2009). Up to now, the bacterial biomass was used in the form of biofilms only supported on granular activated carbon or zeolites for the removal of different heavy metals from aqueous solutions (Figueiredo et al., 2010; Fonseca et al., 2012; Quintelas et al., 2008a, 2009). There is only one study addressing $\mathrm{Cr}$ (VI) reduction and removal from aqueous solutions by $\mathrm{A}$. viscosus biomass itself, but it is limited to the effect of $\mathrm{pH}$ on metal removal (Silva et al., 2009).

Given this context, the objectives of the present work are to evaluate and discuss: (i) the effects of various factors on $\mathrm{Cr}(\mathrm{VI})$ removal efficiency by dead and living A. viscosus in batch operating mode, (ii) the potential of an up-flow bacterial biofilm for $\mathrm{Cr}$ (VI) removal in an open system column, (iii) the mechanism that governs the removal of $\mathrm{Cr}(\mathrm{VI})$ by dead and living biomass of A. viscosus.

\section{Materials and methods}

\subsection{Culture and growth conditions of Arthrobacter viscosus}

The A. viscosus bacterium strain was obtained from the Spanish Type Culture Collection of the University of Valência. For the growth of the microorganism, a medium containing peptone $(5 \mathrm{~g} / \mathrm{L})$, malt extract $(3 \mathrm{~g} / \mathrm{L})$, yeast extract $(3 \mathrm{~g} / \mathrm{L})$ and glucose $(10 \mathrm{~g} / \mathrm{L})$ was used. The $\mathrm{pH}$ of the medium was adjusted to 7 by using concentrated $\mathrm{NaOH}$. Further, the medium was sterilized at $120^{\circ} \mathrm{C}$ for $20 \mathrm{~min}$, inoculated with bacteria and kept at $28^{\circ} \mathrm{C}$ and $150 \mathrm{rpm}$ for $72 \mathrm{~h}$. For the experiments involving dead A. viscosus, the bacterial biomass was centrifuged at $7000 \mathrm{rpm}$ for $10 \mathrm{~min}$ and deactivated by drying in an oven at $55^{\circ} \mathrm{C}$ for $72 \mathrm{~h}$. The dried biomass of $\mathrm{A}$. viscosus was crushed and sieved to $125-250 \mu \mathrm{m}$ particle size and stored in a desiccator until further use. For the experiments with living A. viscosus biomass, after inoculation and incubation, the liquid containing A. viscosus biomass was centrifuged at $7000 \mathrm{rpm}$ for
$10 \mathrm{~min}$. Afterwards, the biomass was resuspended in distilled water and kept at $4{ }^{\circ} \mathrm{C}$ until different sets of experiments were developed.

\subsection{Reagents and equipments}

All chemicals used in this investigation were of analytical grade and no further purification was necessary. A stock solution of $1000 \mathrm{mg} / \mathrm{L} \mathrm{Cr}(\mathrm{VI})$ was prepared by dissolving $\mathrm{K}_{2} \mathrm{Cr}_{2} \mathrm{O}_{7}$ (Riedel) in distilled water. The solution was diluted for different $\mathrm{Cr}(\mathrm{VI})$ concentrations using distilled water as required by the working procedure. The concentration of total $\mathrm{Cr}$ in liquid samples was determined by an Atomic Absorption Spectrophotometer (Varian Spectra AA-400 type). In parallel, samples of $\mathrm{Cr}(\mathrm{VI})$ were analyzed spectrophotometrically by measuring the absorbance of the pink colored complex of $\mathrm{Cr}(\mathrm{VI})$ with 1,5-diphenylcarbazide in acidic solution at $540 \mathrm{~nm}$ (T60 UV-Visible Spectrophotometer) as described in the Standard Methods (Clesceri et al., 2005). The concentrations of $\mathrm{Cr}$ (III) were obtained by the difference between total $\mathrm{Cr}$ and $\mathrm{Cr}(\mathrm{VI})$ concentrations.

\subsection{Batch experimental procedure}

Experiments regarding the biosorption of $\mathrm{Cr}(\mathrm{VI})$ by both dead and living biomass categories were carried out in batch mode at selected $\mathrm{pH}$ values, at various contact times and biomass dosages. Erlenmeyer flasks of $250 \mathrm{~mL}$ were used for batch experiments with $100 \mathrm{~mL}$ of working volume containing $\mathrm{Cr}(\mathrm{VI})$ solution of known concentrations together with biomass and agitated in an orbital incubator at $150 \mathrm{rpm}$. The effect of $\mathrm{pH}$ on $\mathrm{Cr}$ (VI) removal efficiency was investigated by varying the solution $\mathrm{pH}$ from 1 to 4 , while biomass dosages of $1-8 \mathrm{~g} / \mathrm{L}$ were used. In experiments developed to investigate the effect of initial $\mathrm{Cr}(\mathrm{VI})$ concentration, concentrations of $25-250 \mathrm{mg} / \mathrm{L}$ were used, while in experiments performed to evaluate the contact time dependence on removal efficiency, concentrations of 25 , 50 and $100 \mathrm{mg} / \mathrm{L}$ were used.

Thermodynamic studies were also conducted for the biosorption of $\mathrm{Cr}(\mathrm{VI})$ by dead $\mathrm{A}$. viscosus biomass by establishing a temperature interval of $26-50^{\circ} \mathrm{C}$. The initial $\mathrm{pH}$ of working solutions was adjusted by addition of $0.1 \mathrm{M} \mathrm{H}_{2} \mathrm{SO}_{4}$ and $0.1 \mathrm{M} \mathrm{NaOH}$ solutions. The change in the working volume due to the addition of $\mathrm{H}_{2} \mathrm{SO}_{4}$ and $\mathrm{NaOH}$ was negligible. Control experiments (without heavy metal) were also conducted for each investigation by considering the same procedure stated above. After sampling, the solutions were centrifuged at 13,000 rpm for $5 \mathrm{~min}$, then the $\mathrm{Cr}(\mathrm{VI})$ and total $\mathrm{Cr}$ concentrations in the supernatant were measured. The total chromium uptake $\left(q_{\mathrm{Cr}_{\text {tot }}}\right)$ was calculated using the mass balance equation (Eq. (1)):

$q_{\mathrm{Cr}_{\text {tot }}}=\frac{\left(C_{\mathrm{i}}-\mathrm{C}_{\mathrm{f}}\right) \cdot \mathrm{V}}{m}$

where $C_{i}$ and $C_{f}$ are the initial and final total chromium concentrations $(\mathrm{mg} / \mathrm{L})$, respectively, $\mathrm{V}$ is the solution volume $(\mathrm{L})$, and $m$ is the mass of biomass used in experiments (g).

The removal efficiency (\%) was calculated using Eq. (2):

Removal efficiency $(\%)=\frac{C_{i}-C_{f}}{C_{i}} \cdot 100$ 
All experiments were carried out in duplicate and the mean average values were used in further analysis. The experimental error was less than $5 \%$.

\subsection{Column biosorption experiments}

The removal of $\mathrm{Cr}(\mathrm{VI})$ was investigated using $\mathrm{A}$. viscosus biofilm supported on a new type of polyethylene, developed by researchers at University of Minho and consisting of hollow, star-shaped carriers with $17 \mathrm{~mm}$ external diameter and a height of $10 \mathrm{~mm}$ (Nogueira et al., 2009). The supports (38.36 g) were initially placed in an acrylic column $(25 \mathrm{~cm} \times 3.2 \mathrm{~cm})$ and washed for $24 \mathrm{~h}$ with hypochlorite solution for sterilization. Afterwards, the supports were washed with distilled water. The microorganism culture was previously grown for $72 \mathrm{~h}$ in an orbital incubator as explained in Section 2.1 and was pumped upwards at a flow rate of $19 \mathrm{~mL} / \mathrm{min}$. This high flow rate allows optimal formation and adhesion of a compact biofilm, resistant to erosion stress resulting from the hydrodynamic forces (Quintelas et al., 2008a). The culture medium was used to grow the microorganism on the support for $120 \mathrm{~h}$. After this time period, the biofilm formation could be observed by naked eye. Next, the $\mathrm{Cr}(\mathrm{VI})$ solution $(25 \mathrm{mg} / \mathrm{L}$, pH 2, room temperature) was passed through the column at a flow rate of $10 \mathrm{~mL} / \mathrm{min}$ to avoid breaking of the formed A. viscosus biofilm. Samples of $5 \mathrm{~mL}$ were withdrawn from the effluent, centrifuged and analyzed for chromium content. The metal solution continued to pass until reaching the influent-effluent $\mathrm{Cr}$ (VI) concentration equilibrium. This indicated that no further metal reduction/sorption was occurring.

The total $\mathrm{Cr}$ mass biosorbed on the column bed $\left(m_{\mathrm{ad}}\right)$ is calculated from the area above the breakthrough curve (effluent metal concentration versus time) multiplied by flow rate. Dividing this mass $\left(m_{\mathrm{ad}}\right)$ by the biosorbent mass $(M)$ leads to the uptake capacity (q) of the biomass (Vijayaraghavan et al., 2005).

\subsection{Modeling of $\mathrm{Cr}(\mathrm{VI})$ biosorption}

Authors have reported that the biosorption mechanism of $\mathrm{Cr}$ (VI) by biomaterials is not an "anionic adsorption" but "adsorption-coupled reduction" process (Park et al., 2005, 2006, 2007, 2008; Wu et al., 2010). Therefore, classical kinetic models based on reduction and adsorption were applied to fit the experimental data as follows (Eqs. (3)-(6)) (Ho, 2006; Wu et al., 2010):

Pseudo-first order reduction:

$\frac{d C}{d t}=-k_{1} C, \quad \ln C=\ln C_{0}-k_{1} t$

Pseudo-second order reduction:

$\frac{d C}{d t}=-k_{2} C^{2}, \quad \frac{1}{C}=k_{2} t+\frac{1}{C_{0}}$

Pseudo-first order adsorption:

$$
\frac{d q}{d t}=-k_{3}\left(q_{e}-q\right), \quad \ln \left(q_{e}-q\right)=\ln q_{e}-k_{3} t
$$

Pseudo-second order adsorption:

$$
\frac{d q}{d t}=-k_{4}\left(q_{e}-q\right)^{2}, \quad \frac{1}{q_{e}-q}=\frac{1}{q_{e}}+k_{4} t
$$

where $C_{0}$ and $C$ are $\mathrm{Cr}(\mathrm{VI})$ concentrations in solution $(\mathrm{mg} / \mathrm{L})$ at time 0 and $t$ respectively, $q$ and $q_{\mathrm{e}}$ are the amount of $\mathrm{Cr}(\mathrm{VI})$ adsorbed at time $t$ and at equilibrium per gram of sorbent $(\mathrm{mg} / \mathrm{g})$, and $k_{1}, k_{2}, k_{3}, k_{4}$ are the apparent rate constants.

With respect to isotherm modeling, Langmuir model was applied (Eq. (7)):

$q_{\mathrm{Cr}_{\text {tot }}}=\frac{q_{\mathrm{Cr}_{\text {tot }}}^{\max } b\left[\mathrm{Cr}_{\text {tot }}\right]}{1+b\left[\mathrm{Cr}_{\text {tot }}\right]}(\mathrm{mg} / \mathrm{g})$

where $q_{C r}$ is the amount of total $\mathrm{Cr}$ bound to the biomass $(\mathrm{mg} / \mathrm{g}), q_{\mathrm{Cr}}^{\max }$ is the maximum amount of total $\mathrm{Cr}$ bound at high [ $\left.\mathrm{Cr}_{\text {tot }}\right](\mathrm{mg} / \mathrm{g})$ and $b$ is a constant related to the affinity of the binding sites $(\mathrm{mg} / \mathrm{L})$. (8):

Thermodynamic parameters are calculated by using the Eq.

$\ln K_{d}=\frac{\Delta S^{\circ}}{R}-\frac{\Delta H^{\circ}}{R T}$

where $\Delta H^{\circ}, \Delta S^{\circ}$ and $T$ are the enthalpy, entropy, and temperature, respectively, and $R$ is the gas constant. The values of enthalpy $\left(\Delta H^{\circ}\right)$ and entropy $\left(\Delta S^{\circ}\right)$ are obtained from the slope and intercept of $\ln K_{d}$ vs. $1 / T$ plots.

The distribution coefficient $\left(K_{d}\right)$ is calculated from the concentration of total chromium in suspension $\left(C_{0}\right)$ and that of total chromium in supernatant $\left(C_{e}\right)$ after centrifugation according to Eq. (9):

$K_{\mathrm{d}}=\frac{C_{0}-C_{e}}{C_{e}} \frac{V}{m}$

where $\mathrm{V}$ is the volume of the solution (L) and $m$ is the mass of dead biomass (g) (Hlihor et al., 2015).

The change of Gibbs free energy $\left(\Delta G^{\circ}\right)$ was calculated from Eq. (10):

$\Delta G^{\circ}=\Delta H^{\circ}-\mathrm{T} \Delta S^{\circ}$

Different models parameters were evaluated using OriginPro 8 software.

\subsection{FTIR analysis}

Infrared spectra of dead and living A. viscosus biomass, with and without metal ion were acquired by using a BOMEN MB 104 spectrometer. The dried samples were prepared with $\mathrm{KBr}$ at a proportion of $1 \mathrm{mg}$ sample per $100 \mathrm{mg}$ of $\mathrm{KBr}$ and analyzed in the range $4000-500 \mathrm{~cm}^{-1}$ with a resolution of $8 \mathrm{~cm}^{-1}$.

\section{Results and discussion}

\subsection{Removal of $\mathrm{Cr}$ (VI) ions: reduction to $\mathrm{Cr}$ (III) and biosorption by dead biomass of $\mathrm{A}$. viscosus}

\subsubsection{Effect of $\mathrm{pH}$ on $\mathrm{Cr}(\mathrm{VI})$ reduction and total $\mathrm{Cr}$ removal}

Solution $\mathrm{pH}$ was found to be one of the most important parameters in sorption processes, since it affects not only the speciation of metal ions but also the availability of sorption sites (Hlihor et al., 2015; Park et al., 2007; Wang et al., 2008). In order to study the effect of initial $\mathrm{pH}$ on $\mathrm{Cr}(\mathrm{VI})$ removal by dead A. viscosus biomass, experiments were conducted for $\mathrm{pH}$ values ranging from 1 to 4 with an initial $\mathrm{Cr}(\mathrm{VI})$ concentration of $100 \mathrm{mg} / \mathrm{L}$ at $26^{\circ} \mathrm{C}$ (Fig. 1). Results revealed that the removal 


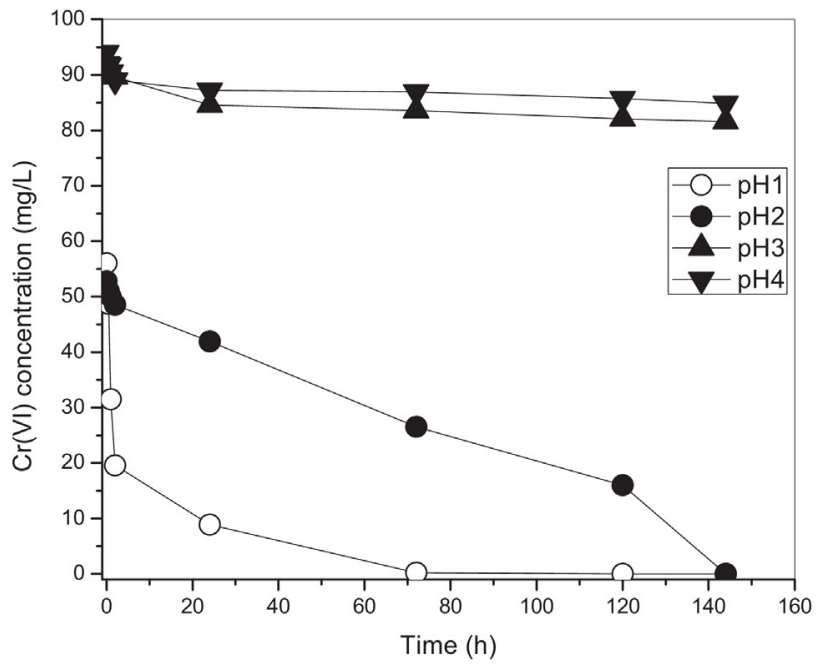

a)

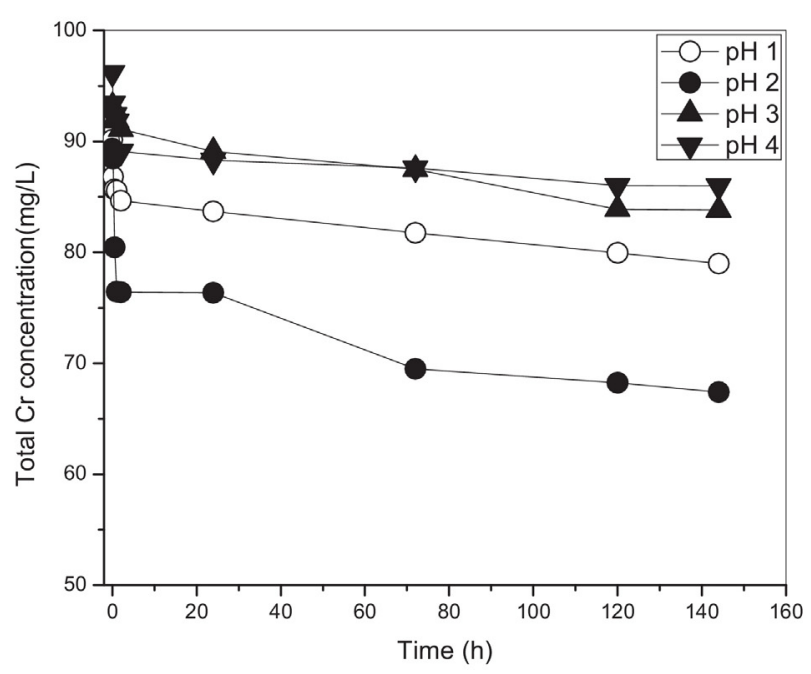

b)

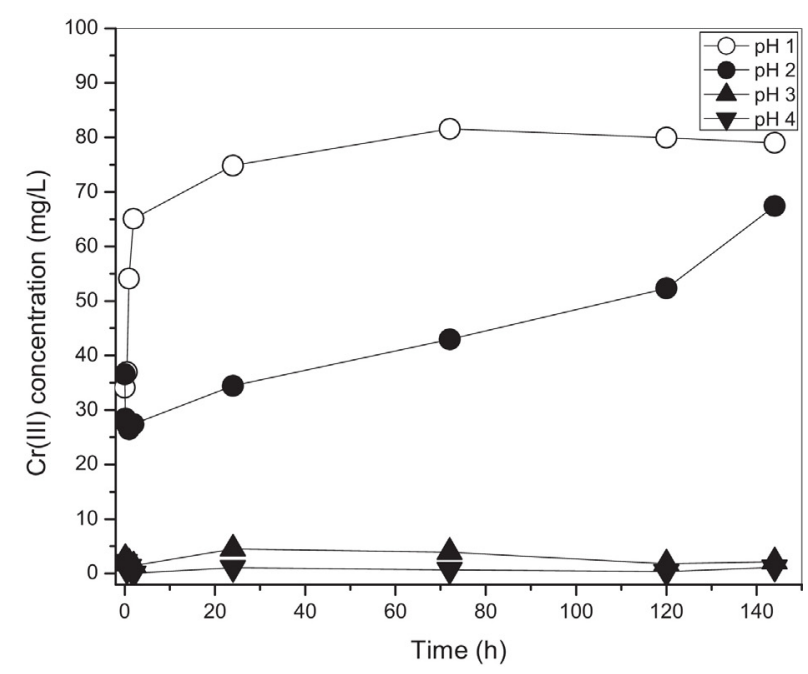

c)

Fig. 1 - Effect of solution $\mathrm{pH}$ on chromium reduction and biosorption from aqueous solution using dead A. viscosus: (a) $\mathrm{Cr}$ (VI) concentration vs. time, (b) Total $\mathrm{Cr}$ concentration vs. time, (c) $\mathrm{Cr}$ (III) concentration vs. time (biomass dosage: $5 \mathrm{~g} / \mathrm{L}$; initial $\mathrm{Cr}(\mathrm{VI})$ concentration: $100 \mathrm{mg} / \mathrm{L}$; temperature: $26^{\circ} \mathrm{C}$; contact time: $144 \mathrm{~h}$ ). efficiency was $100 \%$ at $\mathrm{pH} 1-2$, for $5 \mathrm{~g} / \mathrm{L}$ of dead A. viscosus. The necessary time for a complete removal of $\mathrm{Cr}(\mathrm{VI})$ at $\mathrm{pH} 1$ was $72 \mathrm{~h}$, while at pH 2 it was double, of $144 \mathrm{~h}$ (Fig. 1a). For the initial $\mathrm{Cr}(\mathrm{VI})$ solution of $\mathrm{pH} 3$ or 4 , the removal efficiency reached only $15.76 \%$ and $13.18 \%$ respectively, after $144 \mathrm{~h}$. Several studies discuss the dynamics of $\mathrm{Cr}(\mathrm{VI})$ removal rate as increasing with decreasing the $\mathrm{pH}$ for various biomass types (Bai and Abraham, 2001; Nourbakhsh et al., 1994; Park et al., 2005; Zhang et al., 2015)

The removal efficiency of total $\mathrm{Cr}$ was also found to be dependent on $\mathrm{pH}$ values. At $\mathrm{pH} 2$, the removal efficiency was of $31 \%$, while at $\mathrm{pH} 1$, the removal efficiency was of $17.9 \%$. Therefore, $\mathrm{pH} 2$ seems to be the optimal value for total $\mathrm{Cr}$ removal (Fig. 1b). The appearance of $\mathrm{Cr}$ (III) in solution is a clear evidence of the reduction of $\mathrm{Cr}$ (VI) to $\mathrm{Cr}$ (III) (Fig. 1c).

Considering the above information, we observed that the removal efficiency of $\mathrm{Cr}(\mathrm{VI})$ ions tends to decrease with any increase in $\mathrm{pH}$. The results obtained indicate that $\mathrm{Cr}(\mathrm{VI})$ removal is highly $\mathrm{pH}$ dependent as also suggested by several researchers (Hlihor et al., 2013; Park et al., 2005; Samuel et al., 2015; Silva et al., 2009; Wang et al., 2008). The same trend of $\mathrm{pH}$ influence on $\mathrm{Cr}(\mathrm{VI})$ reduction and removal by biomaterials was reported by other authors (Cabatingan et al., 2001; Kumar et al., 2008; Silva et al., 2009; Wu et al., 2010). The observed behavior of $\mathrm{Cr}(\mathrm{VI})$ sorption at various $\mathrm{pH}$ values is a consequence of various mechanisms which are responsible for adsorption on surface (electrostatic attraction/repulsion, chemical interactions etc.) (Baral et al., 2006).

Donmez et al. (1999) revealed that the most prevalent forms of $\mathrm{Cr}(\mathrm{VI})$ in solution seems to be acid chromate $\left(\mathrm{HCrO}_{4}{ }^{-}\right)$, chromate $\left(\mathrm{CrO}_{4}{ }^{2-}\right)$, dichromate $\left(\mathrm{Cr}_{2} \mathrm{O}_{7}{ }^{2-}\right)$ and other $\mathrm{Cr}$ oxyanions. At low $\mathrm{pH}, \mathrm{HCrO}_{4}{ }^{-}$species are dominant and enter in reactions when $\mathrm{Cr}(\mathrm{VI})$ is reduced to $\mathrm{Cr}(\mathrm{III})$.

The reactions leading to reduction of $\mathrm{Cr}(\mathrm{VI})$ to $\mathrm{Cr}$ (III) can be summarized as follows (Eqs. (11) and (12)):

$\mathrm{HCrO}_{4}^{-}+7 \mathrm{H}^{+}+3 \mathrm{e}^{-}=\mathrm{Cr}^{3+}+4 \mathrm{H}_{2} \mathrm{O}$
$\mathrm{Cr}_{2} \mathrm{O}_{7}^{2-}+14 \mathrm{H}^{+}+6 \mathrm{e}^{-}=2 \mathrm{Cr}^{3+}+7 \mathrm{H}_{2} \mathrm{O}$

Both pH 1 and pH 2 are favorable for the reduction of $\mathrm{Cr}(\mathrm{VI})$ to $\mathrm{Cr}(\mathrm{III})$, but at $\mathrm{pH} 1$ biomass is most likely fully protonated and will limit the affinity for $\mathrm{Cr}$ (III) because of the charge repulsion between the cation and surface. At pH 2, the biomass protonation may occur to a lesser degree and the surface will have enough negative charges (or negative functional groups) to attract the $\mathrm{Cr}$ (III) cations. At higher hydrogen ion concentrations, the negative charges at the surface of the biomass are neutralized, so that new adsorption sites may be available, providing a positive charge for the adsorption of chromium ions (Silva et al., 2009; Singh et al., 2005).

Taking into consideration $\mathrm{Cr}(\mathrm{VI})$ reduction and total chromium sorption, $\mathrm{pH} 2$ was selected in further experiments.

\subsubsection{Effect of biomass dosage on $\mathrm{Cr}(\mathrm{VI})$ reduction and} total $\mathrm{Cr}$ removal

A series of experiments addressing the effect of biomass dosage on $\mathrm{Cr}(\mathrm{VI})$ removal efficiency were performed at different initial dosages of sorbent, in the range 1-8 g/L, while working at $\mathrm{pH} 2$ and $26^{\circ} \mathrm{C}$ (Fig. 2). The results revealed that the removal of $\mathrm{Cr}(\mathrm{VI})$ is enhanced with increasing of biomass dosage (Fig. 2a), i.e. the removal efficiency varies from $26.9 \%$ (for $1 \mathrm{~g} / \mathrm{L}$ sorbent) to $100 \%$ (for $5 \mathrm{~g} / \mathrm{L}$ and $8 \mathrm{~g} / \mathrm{L}$ biomass) for a contact time of $144 \mathrm{~h}$, the duration of the experiment. Therefore, 


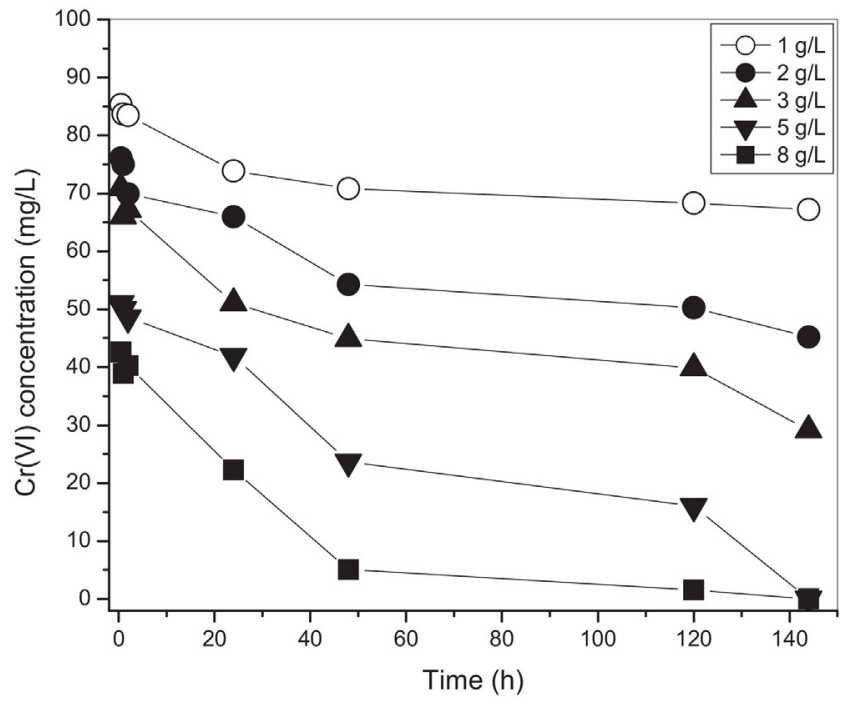

a)

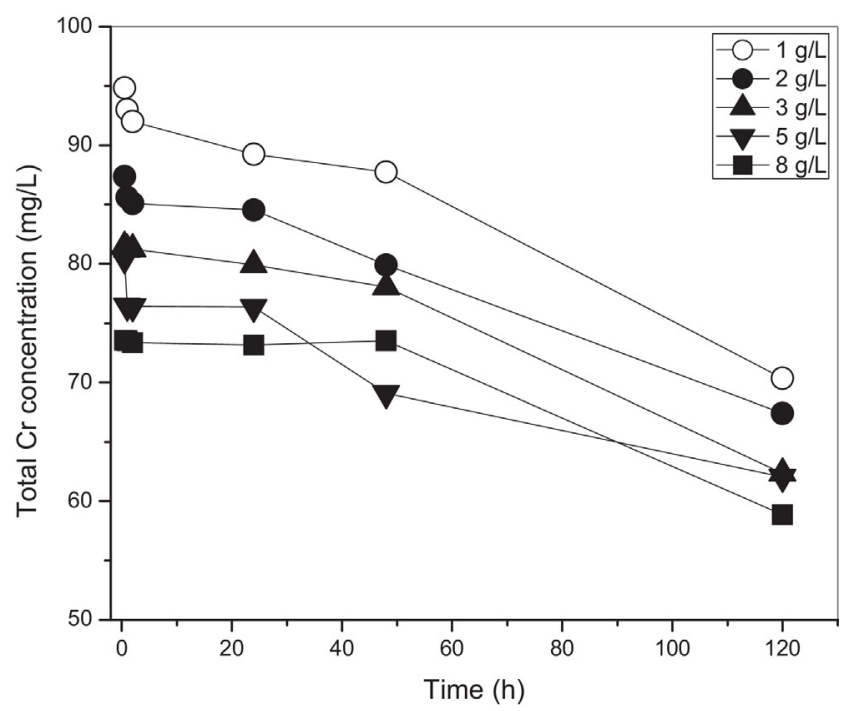

b)

Fig. 2 - Effect of biomass dosage on chromium reduction and biosorption from aqueous solution using dead $A$. viscosus: (a) $\mathrm{Cr}(\mathrm{VI})$ concentration vs. time, (b) total $\mathbf{C r}$ concentration vs. time (initial $\mathrm{Cr}(\mathrm{VI})$ concentration: $100 \mathrm{mg} / \mathrm{L}$; temperature: $26^{\circ} \mathrm{C}$; contact time: $144 \mathrm{~h}$; pH 2).

the $\mathrm{Cr}(\mathrm{VI})$ removal rate was enhanced as biomass dosage was increased. The extent of reduction/sorption increases rapidly in the first $40-50 \mathrm{~h}$, but becomes slower in the later stages.

Also the removal efficiency of total $\mathrm{Cr}$ increased from 32.2 to $43.5 \%$ in $120 \mathrm{~h}$, with increasing the biomass dosage (Fig. 2b). Lower chromium concentrations and high biomass dosages lead to a shorter reduction time, enhancing the removal ratio. For further studies $5 \mathrm{~g} / \mathrm{L}$ of dead A. viscosus biomass was selected as biosorbent dosage, as it showed good reduction and removal of $\mathrm{Cr}(\mathrm{VI})$ and total $\mathrm{Cr}$, respectively.

\subsubsection{Effect of contact time on $\mathrm{Cr}(\mathrm{VI})$ reduction and total Cr removal}

Fig. 3 shows the time-dependency curves of $\mathrm{Cr}(\mathrm{VI})$ reduction and total $\mathrm{Cr}$ removal by dead A. viscosus biomass. The concentration changes of $\mathrm{Cr}(\mathrm{VI})$ along time were followed for $\mathrm{Cr}(\mathrm{VI})$ initial concentrations of $25 \mathrm{mg} / \mathrm{L}, 50 \mathrm{mg} / \mathrm{L}$ and $100 \mathrm{mg} / \mathrm{L}$, while working at $\mathrm{pH} 2$ with $5 \mathrm{~g} / \mathrm{L}$ dead A. viscosus biomass

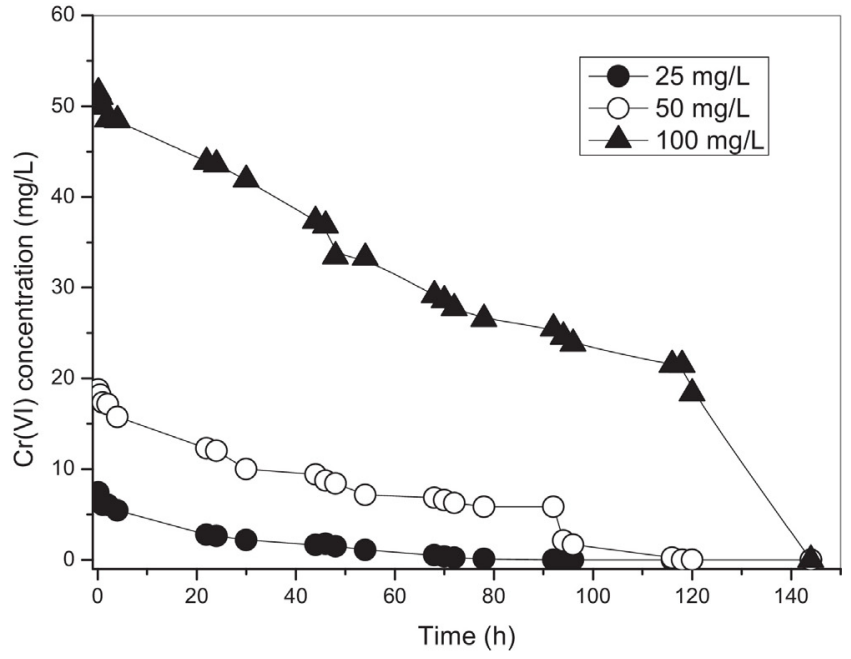

a)

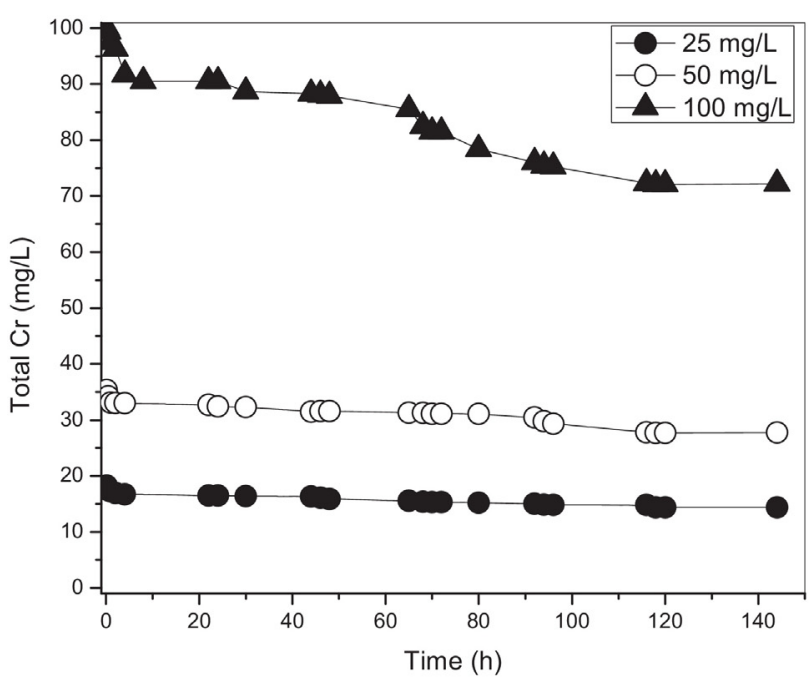

b)

Fig. 3 - (a) The effect of contact time on $\mathrm{Cr}(\mathrm{VI})$ reduction by dead A. viscosus; (b) The effect of contact time on total $\mathrm{Cr}$ removal by dead $A$. viscosus (temperature: $26^{\circ} \mathrm{C}$; contact time: $144 \mathrm{~h} ; \mathrm{pH} 2$ ).

and at $26^{\circ} \mathrm{C}$. For $\mathrm{Cr}(\mathrm{VI})$ initial concentration of $25 \mathrm{mg} / \mathrm{L}$, it was observed that $\mathrm{Cr}(\mathrm{VI})$ was completely reduced to $\mathrm{Cr}$ (III) in $92 \mathrm{~h}$, for $50 \mathrm{mg} / \mathrm{L}$ initial concentration, $\mathrm{Cr}(\mathrm{VI})$ was completely reduced in $116 \mathrm{~h}$, while the complete removal of $100 \mathrm{mg} / \mathrm{L}$ of $\mathrm{Cr}$ (VI) required about $144 \mathrm{~h}$ of contact time (Fig. 3a). When the removal of total $\mathrm{Cr}$ was evaluated (Fig. 3b), we could observe a removal efficiency of $43.5 \%$ for $100 \mathrm{mg} / \mathrm{L}$ initial $\mathrm{Cr}(\mathrm{VI})$ concentration, of $42.6 \%$ for $50 \mathrm{mg} / \mathrm{L}$ initial $\mathrm{Cr}(\mathrm{VI})$ concentration and $42.3 \%$ for $25 \mathrm{mg} / \mathrm{L}$ initial $\mathrm{Cr}(\mathrm{VI})$ concentration, again in $144 \mathrm{~h}$.

\subsubsection{Sorption kinetics}

In order to develop the kinetic models of $\mathrm{Cr}(\mathrm{VI})$ removal by A. viscosus, reduction kinetics and adsorption kinetic models (Eqs. (3)-(6)) were applied to the experimental data. The effects of the initial $\mathrm{Cr}(\mathrm{VI})$ concentration, $\mathrm{pH}$ and biomass dosage were investigated to find the best kinetic model, for a better understanding of a possible mechanism of $\mathrm{Cr}(\mathrm{VI})$ removal by A. viscosus. The kinetic constants and correlation coefficients are given in Table 1.

Kinetic models based on reduction reaction, either pseudofirst or pseudo-second order, described the data with the 
Table 1 - Regression parameters of the kinetic models applied for $\mathbf{C r}(\mathrm{VI})$ removal by dead A. viscosus biomass.

\begin{tabular}{|c|c|c|c|c|c|c|}
\hline \multirow[t]{2}{*}{ Kinetic models } & \multirow[t]{2}{*}{ Parameters } & \multirow[t]{2}{*}{ Value } & \multicolumn{2}{|c|}{ Pseudo-first order } & \multicolumn{2}{|c|}{ Pseudo-second order } \\
\hline & & & $k$ & $R^{2}$ & $k$ & $R^{2}$ \\
\hline \multirow{12}{*}{$\begin{array}{l}\text { Reduction } \\
\text { kinetics }\end{array}$} & \multirow{4}{*}{$\begin{array}{l}\mathrm{Cr}(\mathrm{VI}) \\
\text { concentration }\end{array}$} & $25 \mathrm{mg} / \mathrm{L}$ & 0.0308 & 0.9607 & 0.0101 & 0.9876 \\
\hline & & $50 \mathrm{mg} / \mathrm{L}$ & 0.0156 & 0.9746 & 0.0012 & 0.9821 \\
\hline & & $100 \mathrm{mg} / \mathrm{L}$ & 0.0071 & 0.9267 & 0.0001 & 0.9165 \\
\hline & & 1 & 0.0728 & 0.9684 & 0.0631 & 0.88763 \\
\hline & \multirow{3}{*}{$\mathrm{pH}$} & 2 & 0.0071 & 0.9267 & 0.0001 & 0.9165 \\
\hline & & 3 & $7.34 \mathrm{E}-4$ & 0.8284 & $8.58 \mathrm{E}-6$ & 0.8360 \\
\hline & & 4 & $5.23 \mathrm{E}-4$ & 0.68724 & $5.91 \mathrm{E}-6$ & 0.6995 \\
\hline & \multirow{5}{*}{ Biomass dosage } & $1 \mathrm{~g} / \mathrm{L}$ & 0.0015 & 0.7593 & $2.04 \mathrm{E}-5$ & 0.7811 \\
\hline & & $2 \mathrm{~g} / \mathrm{L}$ & 0.0033 & 0.8943 & $5.69 \mathrm{E}-5$ & 0.9196 \\
\hline & & $3 \mathrm{~g} / \mathrm{L}$ & 0.0052 & 0.8891 & $1.15 \mathrm{E}-4$ & 0.8927 \\
\hline & & $5 \mathrm{~g} / \mathrm{L}$ & 0.0071 & 0.9267 & 0.0001 & 0.9165 \\
\hline & & $8 \mathrm{~g} / \mathrm{L}$ & 0.0285 & 0.9305 & 0.0051 & 0.9589 \\
\hline \multirow{12}{*}{$\begin{array}{l}\text { Adsorption } \\
\text { kinetics }\end{array}$} & \multirow{4}{*}{$\begin{array}{l}\mathrm{Cr}(\mathrm{VI}) \\
\text { concentration }\end{array}$} & $25 \mathrm{mg} / \mathrm{L}$ & 0.0308 & 0.9677 & 0.0507 & 0.9876 \\
\hline & & $50 \mathrm{mg} / \mathrm{L}$ & 0.0156 & 0.9746 & 0.0063 & 0.9821 \\
\hline & & $100 \mathrm{mg} / \mathrm{L}$ & 0.0127 & 0.9180 & 0.0027 & 0.8780 \\
\hline & & 1 & 0.0728 & 0.9684 & $9.56 \mathrm{E}-6$ & 0.5851 \\
\hline & \multirow{3}{*}{$\mathrm{pH}$} & 2 & 0.0127 & 0.9180 & 0.0027 & 0.8780 \\
\hline & & 3 & 0.0230 & 0.9540 & $1.40 \mathrm{E}-6$ & 0.8235 \\
\hline & & 4 & 0.0170 & 0.8387 & $9.91 \mathrm{E}-7$ & 0.6793 \\
\hline & \multirow{5}{*}{ Biomass dosage } & $1 \mathrm{~g} / \mathrm{L}$ & 0.0232 & 0.9455 & 0.0069 & 0.9733 \\
\hline & & $2 \mathrm{~g} / \mathrm{L}$ & 0.0152 & 0.9093 & $2.26 \mathrm{E}-6$ & 0.8715 \\
\hline & & $3 \mathrm{~g} / \mathrm{L}$ & 0.0111 & 0.8539 & 0.0017 & 0.9616 \\
\hline & & $5 \mathrm{~g} / \mathrm{L}$ & 0.0127 & 0.9180 & 0.0027 & 0.8780 \\
\hline & & $8 \mathrm{~g} / \mathrm{L}$ & 0.0287 & 0.9317 & 0.0424 & 0.9575 \\
\hline
\end{tabular}

highest correlation coefficients, $R^{2}>0.91$. Pseudo-first order equation described well the batch experimental data at $\mathrm{pHs}$ 1 and 2, only for biomass dosages of 5 and $8 \mathrm{~g} / \mathrm{L}$ respectively, indicating possible differences under different $\mathrm{pH}$ conditions and at higher biomass dosages.

\subsubsection{Biosorption isotherms and thermodynamic parameters}

One of the most important aspects of biosorption seen as a mass transfer unit operation is the equilibrium. The equilibrium data allow the development of equations useful for comparison of various biosorbents, under different operational conditions, as well as for optimization and operating purposes (Khambhaty et al., 2009; Yang et al., 2016). As seen from the experimental data, some of the total $\mathrm{Cr}$, i.e. the reduced $\mathrm{Cr}$ (III), was retained by the biomass during $\mathrm{Cr}(\mathrm{VI})$ biosorption process. It might be assumed that the adsorption rate of the reduced $\mathrm{Cr}$ (III) might be faster than the reduction rate of $\mathrm{Cr}(\mathrm{VI})$ and that $\mathrm{Cr}(\mathrm{III})$ remains in equilibrium (Park et al., 2007). Fig. 4 shows the equilibrium isotherm of total $\mathrm{Cr}$ at $\mathrm{pH} 2$, while working at different temperatures ranging from $26^{\circ} \mathrm{C}$ to $50^{\circ} \mathrm{C}$. In order to analyze the differences between sorption and aqueous concentrations of chromium at equilibrium, some isotherm models are available for fitting the data. In the present study, a two-parameter model, i.e. Langmuir isotherm was used to describe the equilibrium of the sorption system. By using Eq. (7), a non-linear regression fitting gave the values of the Langmuir isotherm parameters as follows: for experiments performed at $26^{\circ} \mathrm{C}, q_{\mathrm{Cr}_{\text {tot }}}^{\max }=14.44 \mathrm{mg} / \mathrm{g}$ and $b=0.0019 \mathrm{mg} / \mathrm{L}$; for experiments performed at $40^{\circ} \mathrm{C}, q_{\mathrm{Crtot}}^{\max }=$ $17.32 \mathrm{mg} / \mathrm{g}$ and $b=5.39 \mathrm{E}-4 \mathrm{mg} / \mathrm{L}$; and for experiments performed at $50^{\circ} \mathrm{C}, q_{\mathrm{Crtot}}^{\max }=1089.20 \mathrm{mg} / \mathrm{g}$ and $b=1.43 \mathrm{mg} / \mathrm{L}$. These results show that the maximum uptake of total $\mathrm{Cr}$ occurs at $50^{\circ} \mathrm{C}$. The experimental data show that the equilibrium was attained only when considering working at 26 and $40^{\circ} \mathrm{C}$, while for $50^{\circ} \mathrm{C}$, the A. viscosus seems to be able to remove higher

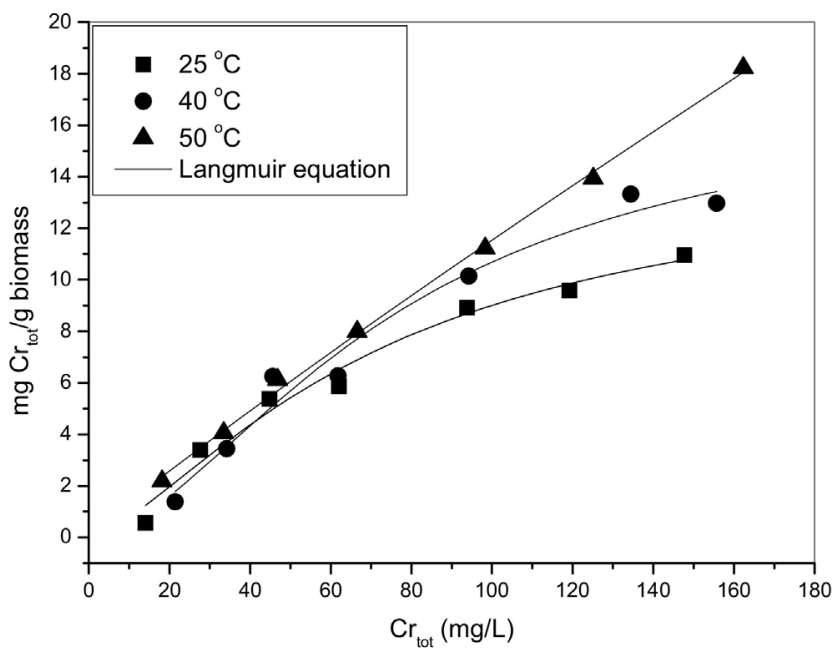

Fig. 4 - Isotherm plot of total $\mathrm{Cr}$ retention at different temperatures (dead biomass dosage, $5 \mathrm{~g} / \mathrm{L}$ ).

concentrations than the ones used in our experiments. In this case, the heavy metal ions are not in equilibrium with the biomass up to a concentration of $250 \mathrm{mg} / \mathrm{L} \mathrm{Cr}(\mathrm{VI})$, so higher concentrations of heavy metal should be considered to attain equilibrium. A similar behavior was reported by Khambhaty et al. (2009), which consider that the enhancement of sorption capacity is the result of an increasing in collision frequency between sorbent and heavy metal. The resulting data was well fitted for the studied temperatures $\left(26^{\circ} \mathrm{C}, 40^{\circ} \mathrm{C}\right.$ and $\left.50^{\circ} \mathrm{C}\right)$, the correlation coefficient being greater than 0.96 in all three cases. This means that the Langmuir model can represent this process very well, possibly due to a homogeneous distribution of active sites available for sorption on the biomass surface (Baral et al., 2006; Park et al., 2005).

Sorption isotherm data obtained at different temperatures were used to calculate the thermodynamic parameters using Eqs. (8)-(10). The calculated values are listed in Table 2. 
Table 2 - The thermodynamic data of total chromium biosorption on dead A. viscosus biomass at different initial chromium concentrations.

\begin{tabular}{lrrrrr}
$C_{\mathrm{i}}(\mathrm{mol} / \mathrm{L})$ & $\Delta \mathrm{H}^{\circ}(\mathrm{kJ} / \mathrm{mol})$ & $\Delta \mathrm{S}^{\circ}(\mathrm{J} / \mathrm{mol} \mathrm{K})$ & & \multicolumn{2}{c}{$\Delta \mathrm{G}^{\circ}(\mathrm{kJ} / \mathrm{mol})$} \\
\cline { 4 - 6 } & & & $299.15 \mathrm{~K}$ & $313.15 \mathrm{~K}$ & $323.15 \mathrm{~K}$ \\
\hline $4.86 \times 10^{-4}$ & 34.35 & 87.98 & 8.03 & 6.79 & 5.91 \\
$19.23 \times 10^{-4}$ & 7.26 & 0.60 & 5.88 & 5.81 & 5.77 \\
$28.84 \times 10^{-4}$ & 5.90 & 14.23 & 6.82 & 6.04 & 5.81 \\
$38.46 \times 10^{-4}$ & 10.50 & 20.20 & 6.53 & 6.25 & 6.90 \\
$48.08 \times 10^{-4}$ & 12.58 & & & & 5.05 \\
\hline
\end{tabular}

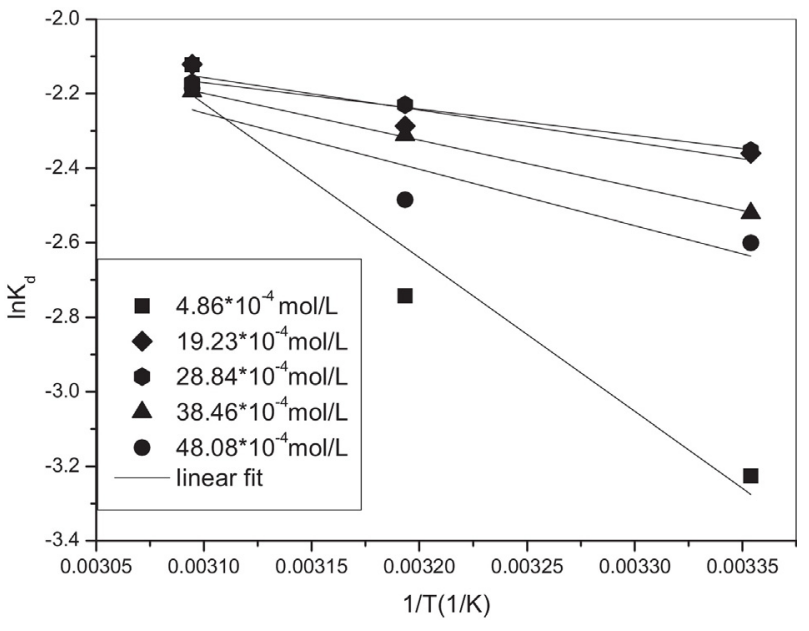

Fig. 5 - Effect of temperature on the distribution coefficient $\left(K_{d}\right)$ of total chromium biosorption on dead $A$. viscosus biomass at different $\mathrm{Cr}(\mathrm{VI})$ concentrations.

The thermodynamic parameters resulted from the slope and intercept of the plot $\ln K_{d}$ vs. 1/T (Fig. 5). As it can be seen from Table 2, the positive enthalpy change $\left(\Delta H^{\circ}\right)$ in the temperature interval 299.15-323.15 K means that the process of chromium removal from solution is endothermic. The positive values of entropy $\left(\Delta S^{\circ}\right)$ reflect the affinity of dead $A$. viscosus biomass toward chromium ions in aqueous solution and may suggest some structural changes in the biosorbent. In a similar context, Loukidou et al. (2004) considered that at higher temperatures, the energy of the system can facilitate the attachment of chromium ions onto cell surface. The positive values of $\Delta G^{\circ}$ indicate a non-spontaneous process for total $\mathrm{Cr}$ biosorption by $\mathrm{A}$. viscosus biomass, while the positive $\Delta \mathrm{S}^{\circ}$ and $\Delta \mathrm{H}^{\circ}$ indicate that the process is spontaneous at high temperatures (Fan et al., 2009).

\subsection{Removal of $\mathrm{Cr}$ (VI) ions: reduction to $\mathrm{Cr}$ (III) and biosorption by living biomass of $A$. viscosus}

\subsubsection{Effect of $\mathrm{pH}$ on $\mathrm{Cr}(\mathrm{VI})$ reduction and total $\mathrm{Cr}$ removal}

Fig. 6 shows the time profiles of $\mathrm{Cr}(\mathrm{VI})$ (Fig. 6a), total $\mathrm{Cr}$ (Fig. 6b) and $\mathrm{Cr}$ (III) (Fig. 6c) removal by living A. viscosus at various solution $\mathrm{pH}$ values. As indicated in the experiments performed up to now, total $\mathrm{Cr}$ was also analyzed to see if the reduction of $\mathrm{Cr}(\mathrm{VI})$ to $\mathrm{Cr}$ (III) is possible as well for the living bacteria as in the case of dead biomass. As seen from Fig. 6, the results also suggest that some of the $\mathrm{Cr}(\mathrm{VI})$ was reduced to $\mathrm{Cr}$ (III) when brought into contact with the living biomass of A. viscosus. Results revealed that $\mathrm{pH} 1$ was the optimum $\mathrm{pH}$ for $100 \%$ removal efficiency of $\mathrm{Cr}(\mathrm{VI})$, starting from a solution of $100 \mathrm{mg} / \mathrm{L} \mathrm{Cr}(\mathrm{VI})$ and working with $5 \mathrm{~g} / \mathrm{L}$ living A. viscosus biomass, at a contact time of $48 \mathrm{~h}$. For pH 2, pH 3 and pH 4, in $96 \mathrm{~h}$, we could observe a removal efficiency of $74.8 \%, 55.1 \%$ and $33.1 \%$, respectively. Compared to $\mathrm{pH} 1, \mathrm{pHs} 2-4$ have a relatively slow reduction rate, a longer contact period being required for $\mathrm{Cr}(\mathrm{VI})$ removal from aqueous media. The removal rate of $\mathrm{Cr}(\mathrm{VI})$ increased with decreasing the $\mathrm{pH}$ value. Additionally, for total $\mathrm{Cr}$ removal, $\mathrm{pH} 2$ seems to be the optimum value. As $\mathrm{pH}$ of the system increases, the number of negatively charged sites increases. Due to the electrostatic repulsion, a negatively charged surface site does not favor the adsorption of anions (Kumar et al., 2008). Bacterial reduction of $\mathrm{Cr}(\mathrm{VI})$ under low $\mathrm{pH}$ conditions and with no addition of nutrients can be considered as a mechanism of resistance to $\mathrm{Cr}(\mathrm{VI})$, including periplasmatic biosorption, intracellular biotransformation either via direct enzymatic reaction or indirectly, via metabolites (Pei et al., 2009). It is also possible that some of the reduced $\mathrm{Cr}(\mathrm{III})$ is being accumulated by the living $\mathrm{A}$. viscosus. The reduction of $\mathrm{Cr}$ (VI) to $\mathrm{Cr}$ (III) has also been reported by some bacterial (Abskharon et al., 2009; Silva et al., 2009; Xu et al., 2011) and fungal strains (Acevedo-Aguilar et al., 2006).

\subsubsection{Effect of biomass dosage on $\mathrm{Cr}(\mathrm{VI})$ reduction and} total $\mathrm{Cr}$ removal

The effect of living A. viscosus biomass dosage in the range of 1 to $8 \mathrm{~g} / \mathrm{L}$ on $\mathrm{Cr}(\mathrm{VI})$ reduction and total $\mathrm{Cr}$ removal at initial pH 1 is shown in Fig. 7. Results showed that the removal of $\mathrm{Cr}(\mathrm{VI})$ (Fig. 7a) reached $100 \%$ and increased with increasing the biomass dosage, from $3 \mathrm{~g} / \mathrm{L}$ to $8 \mathrm{~g} / \mathrm{L}$. Biomass maximum efficiency was achieved in $48 \mathrm{~h}$ for 5 and $8 \mathrm{~g} / \mathrm{L}$ and in $144 \mathrm{~h}$ for $3 \mathrm{~g} / \mathrm{L}$. Also, the removal of total Cr increased from $18 \%$ to $34 \%$ in $144 \mathrm{~h}$ with an increase of biomass dosage (Fig. $7 \mathrm{~b}$ ). High reduction and removal capacity of $\mathrm{Cr}(\mathrm{VI})$ could be observed at low $\mathrm{pH}$ values (1-2), and higher biomass dosages. The reason could be attributed to the large number of $\mathrm{H}^{+}$ions, which neutralize the negatively charged adsorbent surface and to more adsorption sites available at a higher quantity of biosorbent (Ertugay and Bayhan, 2008; Kumar et al., 2008). Hence, 5 g/L of living A. viscosus showed good reduction and removal of $\mathrm{Cr}(\mathrm{VI})$ in a short time period and it was selected as optimum biosorbent dosage.

\subsubsection{Effect of contact time and kinetics of $\mathrm{Cr}(\mathrm{VI})$}

reduction and total $\mathrm{Cr}$ removal

Fig. 8 shows the effect of contact time on $\mathrm{Cr}(\mathrm{VI})$ reduction and total $\mathrm{Cr}$ removal by living A. viscosus. $25 \mathrm{mg} / \mathrm{L}, 50 \mathrm{mg} / \mathrm{L}$ and $100 \mathrm{mg} / \mathrm{L} \mathrm{Cr}(\mathrm{VI})$ solutions were evaluated along time for $48 \mathrm{~h}$, the necessary time for $100 \%$ removal, at $\mathrm{pH} 1$ and $26^{\circ} \mathrm{C}$. For $25 \mathrm{mg} / \mathrm{L}$ and $50 \mathrm{mg} / \mathrm{L}$ of initial $\mathrm{Cr}(\mathrm{VI})$ concentration, total removal was achieved in $4 \mathrm{~h}$ and $20 \mathrm{~h}$ respectively, while the complete removal in the case of $100 \mathrm{mg} / \mathrm{L}$ of $\mathrm{Cr}(\mathrm{VI})$ required $48 \mathrm{~h}$ of contact time (Fig. 8a). In the case of total $\mathrm{Cr}$ removal (Fig. 8b), an efficiency of $51 \%, 40 \%$ and $34 \%$ was noticed in the first $30 \mathrm{~min}$ for $\mathrm{Cr}(\mathrm{VI})$ concentrations of $25 \mathrm{mg} / \mathrm{L}, 50 \mathrm{mg} / \mathrm{L}$ 
Table 3 - Regression parameters of the kinetic models applied for $\mathrm{Cr}(\mathrm{VI})$ removal by living A. viscosus.

\begin{tabular}{|c|c|c|c|c|c|c|}
\hline \multirow[t]{2}{*}{ Kinetic models } & \multirow[t]{2}{*}{ Parameters } & \multirow[t]{2}{*}{ Value } & \multicolumn{2}{|c|}{ Pseudo-first order } & \multicolumn{2}{|c|}{ Pseudo-second order } \\
\hline & & & $k$ & $R^{2}$ & $k$ & $R^{2}$ \\
\hline \multirow{12}{*}{$\begin{array}{l}\text { Reduction } \\
\text { kinetics }\end{array}$} & \multirow{4}{*}{$\begin{array}{l}\mathrm{Cr}(\mathrm{VI}) \\
\text { concentration }\end{array}$} & $25 \mathrm{mg} / \mathrm{L}$ & 0.7942 & 0.8124 & 0.8217 & 0.9966 \\
\hline & & $50 \mathrm{mg} / \mathrm{L}$ & 0.3653 & 0.7456 & 0.0399 & 0.9215 \\
\hline & & $100 \mathrm{mg} / \mathrm{L}$ & 0.04212 & 0.9777 & 0.0025 & 0.9094 \\
\hline & & 1 & 0.06673 & 0.9339 & 0.0047 & 0.9951 \\
\hline & \multirow{3}{*}{$\mathrm{pH}$} & 2 & 0.04212 & 0.9777 & 0.0025 & 0.9094 \\
\hline & & 3 & 0.0063 & 0.8750 & $1.00 \mathrm{E}-4$ & 0.8175 \\
\hline & & 4 & 0.0029 & 0.9562 & $3.76 \mathrm{E}-4$ & 0.9506 \\
\hline & \multirow{5}{*}{ Biomass dosage } & $1 \mathrm{~g} / \mathrm{L}$ & 0.0075 & 0.9990 & $2.50 \mathrm{E}-4$ & 0.9660 \\
\hline & & $2 \mathrm{~g} / \mathrm{L}$ & 0.0182 & 0.9955 & 0.0022 & 0.8409 \\
\hline & & $3 \mathrm{~g} / \mathrm{L}$ & 0.0362 & 0.9923 & 0.01 & 0.7570 \\
\hline & & $5 \mathrm{~g} / \mathrm{L}$ & 0.0421 & 0.9777 & 0.0025 & 0.9094 \\
\hline & & $8 \mathrm{~g} / \mathrm{L}$ & 0.0863 & 0.9990 & 0.0181 & 0.9990 \\
\hline \multirow{12}{*}{$\begin{array}{l}\text { Adsorption } \\
\text { kinetics }\end{array}$} & \multirow{4}{*}{$\begin{array}{l}\mathrm{Cr}(\mathrm{VI}) \\
\text { concentration }\end{array}$} & $25 \mathrm{mg} / \mathrm{L}$ & 0.7942 & 0.8124 & 0.4741 & 0.9914 \\
\hline & & $50 \mathrm{mg} / \mathrm{L}$ & 0.3653 & 0.7456 & 0.1997 & 0.9215 \\
\hline & & $100 \mathrm{mg} / \mathrm{L}$ & 0.7942 & 0.8124 & 0.4108 & 0.9966 \\
\hline & & 1 & 0.0667 & 0.9339 & 0.0237 & 0.9951 \\
\hline & \multirow{3}{*}{$\mathrm{pH}$} & 2 & 0.7942 & 0.81243 & 0.4108 & 0.9966 \\
\hline & & 3 & 0.0124 & 0.7895 & 0.1004 & 0.6909 \\
\hline & & 4 & 0.0200 & 0.8268 & 0.0109 & 0.6933 \\
\hline & \multirow{5}{*}{ Biomass dosage } & $1 \mathrm{~g} / \mathrm{L}$ & 0.0161 & 0.9783 & 0.0010 & 0.8817 \\
\hline & & $2 \mathrm{~g} / \mathrm{L}$ & 0.0139 & 0.9985 & 0.0038 & 0.9070 \\
\hline & & $3 \mathrm{~g} / \mathrm{L}$ & 0.0362 & 0.9923 & 0.03 & 0.7570 \\
\hline & & $5 \mathrm{~g} / \mathrm{L}$ & 0.7942 & 0.8124 & 0.4108 & 0.9966 \\
\hline & & $8 \mathrm{~g} / \mathrm{L}$ & 0.0863 & 0.99 & 0.1211 & 0.99 \\
\hline
\end{tabular}

and $100 \mathrm{mg} / \mathrm{L}$ respectively, and after that, it was kept constant until $48 \mathrm{~h}$. In Table 3 the regression parameters of the kinetic models applied for $\mathrm{Cr}(\mathrm{VI})$ removal by living $\mathrm{A}$. viscosus are presented. Pseudo-first order reduction kinetics described better the experimental data than adsorption kinetics, with a high correlation coefficient for $\mathrm{pHs} 1,2$ and $4 ; R^{2}>0.93$ and $R^{2}>0.97$ were achieved in the case of all kinetics regarding the biomass dosage experiments.

\subsubsection{Biosorption isotherms}

Fig. 9 shows the isotherm plot of total $\mathrm{Cr}$ retention. The model was able to predict the total $\mathrm{Cr}$ biosorption with a correlation coefficient of 0.96 . The Langmuir model parameters with the assumption that the reduced $\mathrm{Cr}$ (III) remains in an equilibrium state between the biomass and aqueous solution were estimated as $q_{\mathrm{Cr}_{\text {tot }}}^{\max }=1161.3 \mathrm{mg} / \mathrm{g}$ and $b=8.38 \mathrm{E}-5 \mathrm{mg} / \mathrm{L}$. In addition, the predicted value of $q_{\mathrm{Cr}}^{\max }$ by Langmuir equation for living biomass was much higher than the experimental one $\left(q_{\mathrm{Cr} \text { tot }}^{\max }=12.4 \mathrm{mg} / \mathrm{g}\right)$. This fact can lead to the conclusion that the biosorption of living biosorbent might follow a heterogeneous model and other mechanisms such as intracellular bioaccumulation would contribute to the uptake of total $\mathrm{Cr}$ except for surface binding (Li et al., 2010).

\subsection{Column study}

For the evaluation of the characteristics of $\mathrm{Cr}(\mathrm{VI})$ removal by $\mathrm{A}$. viscosus biofilm supported on polyethylene, the effluent profiles of $\mathrm{Cr}(\mathrm{VI})$ and total $\mathrm{Cr}$ concentrations were monitored. The column biosorption process required prediction of concentration time profile or breakthrough curve (Fig. 10). Based on the batch studies, the $\mathrm{pH}$ of influent was set at 2. It can be seen from Fig. 10 that for a short period of time (first $5 \mathrm{~min}$ ) the concentration of $\mathrm{Cr}(\mathrm{VI})$ in the column effluent remained zero and then increased reaching the influent level after $350 \mathrm{~min}$. This is due to the formation of the mass transfer zone in the column.
When a fresh layer of the biomass is exposed to a solution that contains a metal, the metal ions are sequestered by the biomass until the retained amount is in equilibrium with the influent concentration (Quintelas et al., 2008b). The amount of biofilm produced on supports could be quantified as $5.75 \mathrm{~g}$ biomass/L of solution. The difference between the total $\mathrm{Cr}$ and $\mathrm{Cr}$ (VI) concentrations was identified as $\mathrm{Cr}(\mathrm{III})$, indicating the reduction of $\mathrm{Cr}(\mathrm{VI})$ by the $\mathrm{A}$. viscosus biofilm. As the operation in the column proceeded, the amount of total $\mathrm{Cr}$ bound to the biomass increased to $20.37 \mathrm{mg} / \mathrm{g}$ at the end of contact time required for establishment of the equilibrium. Previous studies employing biomaterials showed that the chromium bound onto biomass was not in the hexavalent, but in the trivalent form (Park et al., 2006). Our study showed that A. viscosus biofilm has good potential as $\mathrm{Cr}(\mathrm{VI})$ reducing agent with unlimited potential in bioremediation.

\subsection{FTIR analysis}

The FTIR (Fourier Transform Infrared) spectra of unloaded and chromium loaded A. viscosus biomass in the range of $500-4000 \mathrm{~cm}^{-1}$ were analyzed to investigate the functional groups involved in the biosorption process and the possible mechanism that may be involved in the reduction/removal of $\mathrm{Cr}(\mathrm{VI})$. The infrared spectrum of the A. viscosus bacterium (Fig. 11) is typical for bacterial extracellular polymeric substances with a complex mixture of macromolecular polyelectrolytes including polysacharides, proteins, nucleic acids and lipids or humic substances (Figueiredo et al., 2010). As seen in Fig. 11, the unloaded and metal loaded biomass displays a number of absorption peaks, reflecting the complex nature of the biomass. FTIR spectrum of A. viscosus shows one broad band at $3409.81 \mathrm{~cm}^{-1}$ due to the vibrations of hydroxyl (OH stretching) and amino (NH stretching) groups; the small bands in the range between 2975 and $2840 \mathrm{~cm}^{-1}$ are attributed to $\mathrm{C}-\mathrm{H}$ stretching of the groups $\mathrm{CH}_{2}$ and $\mathrm{CH}_{3}$; the 


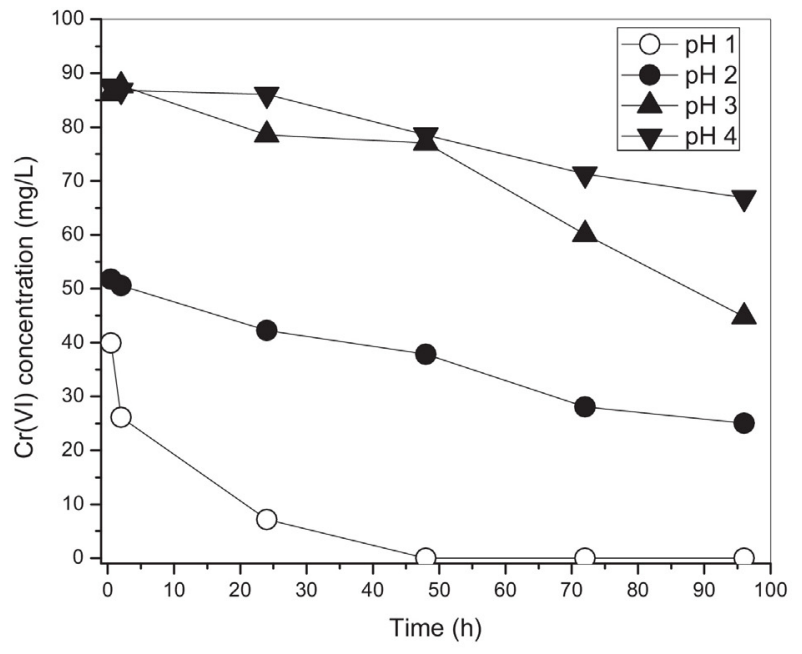

a)

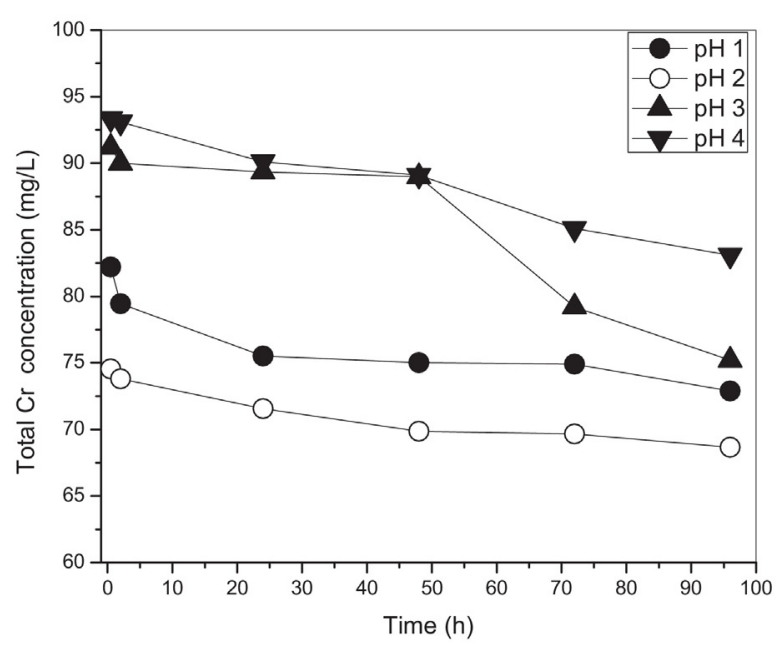

b)

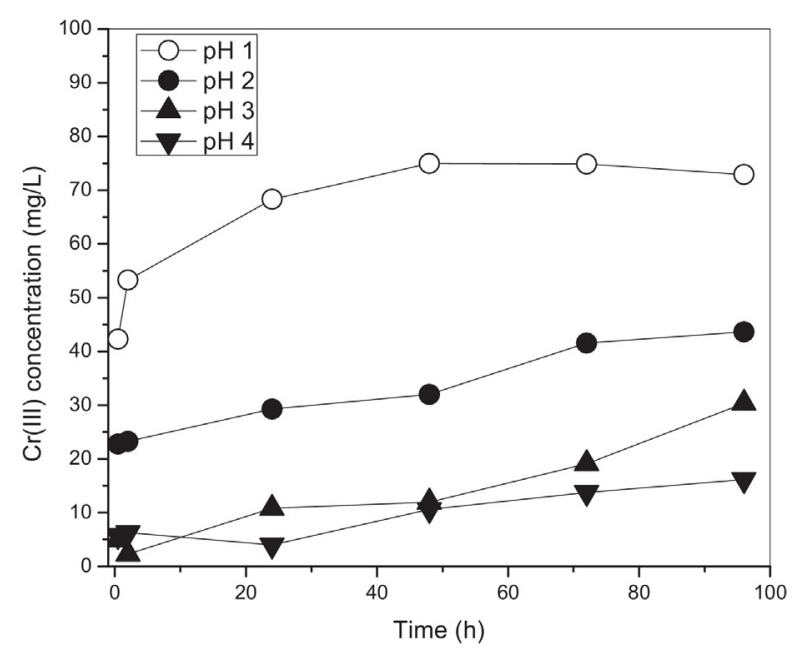

c)

Fig. 6 - Effect of solution $\mathrm{pH}$ on the chromium reduction and biosorption from aqueous solution using living $A$. viscosus: (a) $\mathrm{Cr}(\mathrm{VI})$ concentration vs. time, (b) total $\mathrm{Cr}$ concentration vs. time, c) $\mathrm{Cr}$ (III) concentration vs. time (biomass dosage: $5 \mathrm{~g} / \mathrm{L}$; initial $\mathrm{Cr}(\mathrm{VI})$ concentration: $100 \mathrm{mg} / \mathrm{L}$; temperature: $26^{\circ} \mathrm{C}$; contact time: $96 \mathrm{~h}$ ).

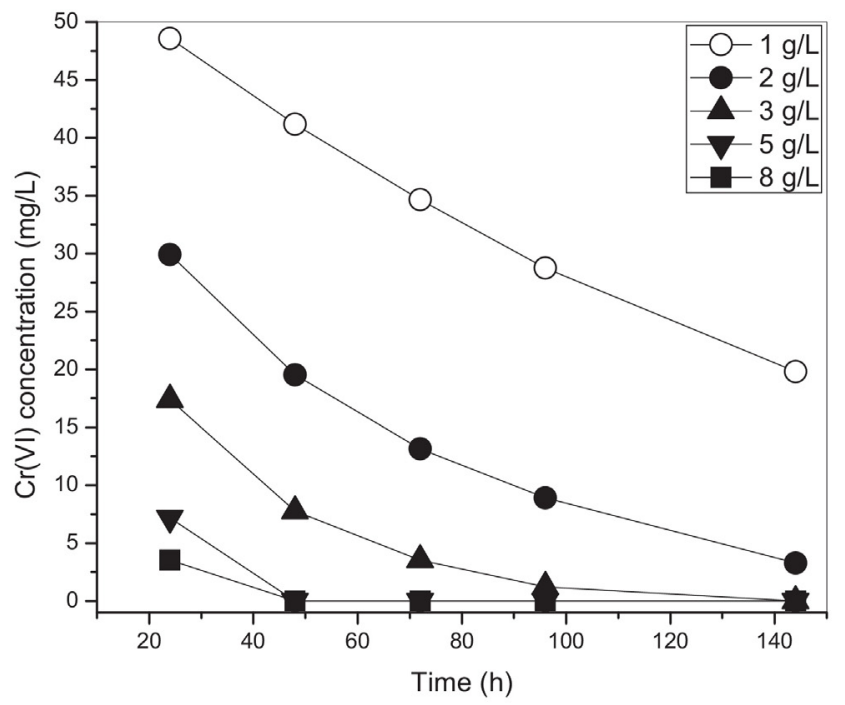

a)

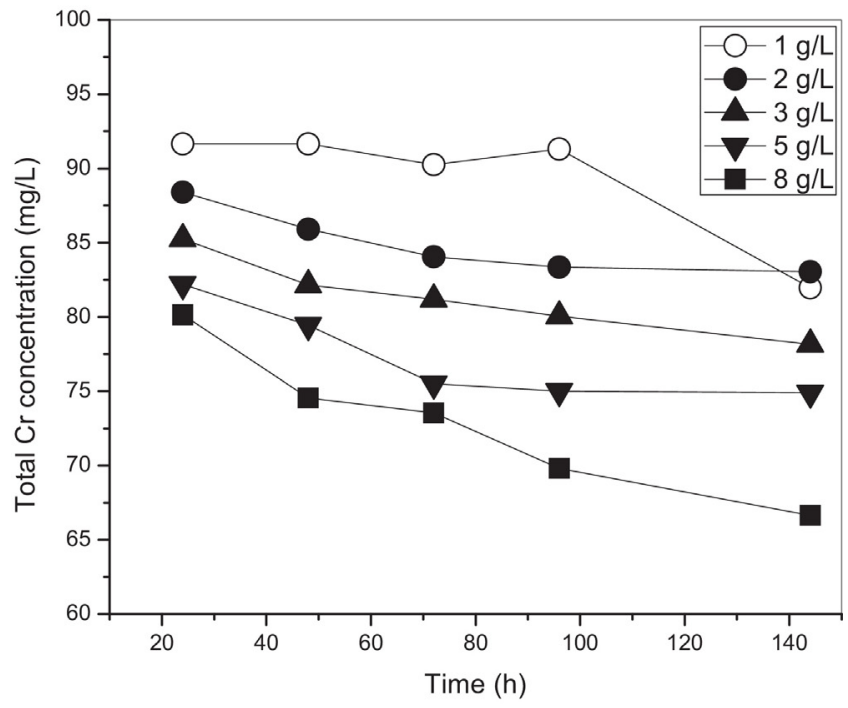

b)

Fig. 7 - Effect of biomass dosage on chromium reduction and biosorption from aqueous solution using living $A$. viscosus: (a) $\mathrm{Cr}(\mathrm{VI})$ concentration vs. time, (b) total $\mathbf{C r}$ concentration vs. time (initial $\mathrm{Cr}(\mathrm{VI})$ concentration: $100 \mathrm{mg} / \mathrm{L}$; temperature: $26^{\circ} \mathrm{C}$; contact time: $144 \mathrm{~h} ; \mathrm{pH} 1$ ).

band at $1539.08 \mathrm{~cm}^{-1}$ is indicative for $\mathrm{C}-\mathrm{N}$ stretching and $\mathrm{N}-\mathrm{H}$ deformation; the characteristic region of the bands between 1660 and $1400 \mathrm{~cm}^{-1}$ are attributed to the vibrations of the functional groups such as carboxyl, phosphoric, amine and the bands in the frequency range of $1250-900 \mathrm{~cm}^{-1}$ result from vibrations of the polysaccharides from the bacterium. The spectrum pattern of the unloaded $A$. viscosus biomass showed changes of certain bands when compared to Cr-loaded biomass. When considering the reduction/removal of $\mathrm{Cr}$ (VI) by the dead A. viscosus biomass, the changes in bands were seen for hydroxyl ( $\mathrm{OH}$ stretching) and amino ( $\mathrm{NH}$ stretching) groups, $\mathrm{C}-\mathrm{H}$ stretching of the groups $\mathrm{CH}_{2}$ and $\mathrm{CH}_{3}, \mathrm{C}-\mathrm{N}$ stretching and $\mathrm{N}-\mathrm{H}$ deformation and for the functional groups such as carboxyl, phosphoric or amine. In the case of the living biomass, $\mathrm{C}-\mathrm{N}$ stretching, $\mathrm{N}-\mathrm{H}$ deformation and functional groups such as carboxyl, phosphoric or amine are indicative for the reduction/removal of $\mathrm{Cr}(\mathrm{VI})$. 


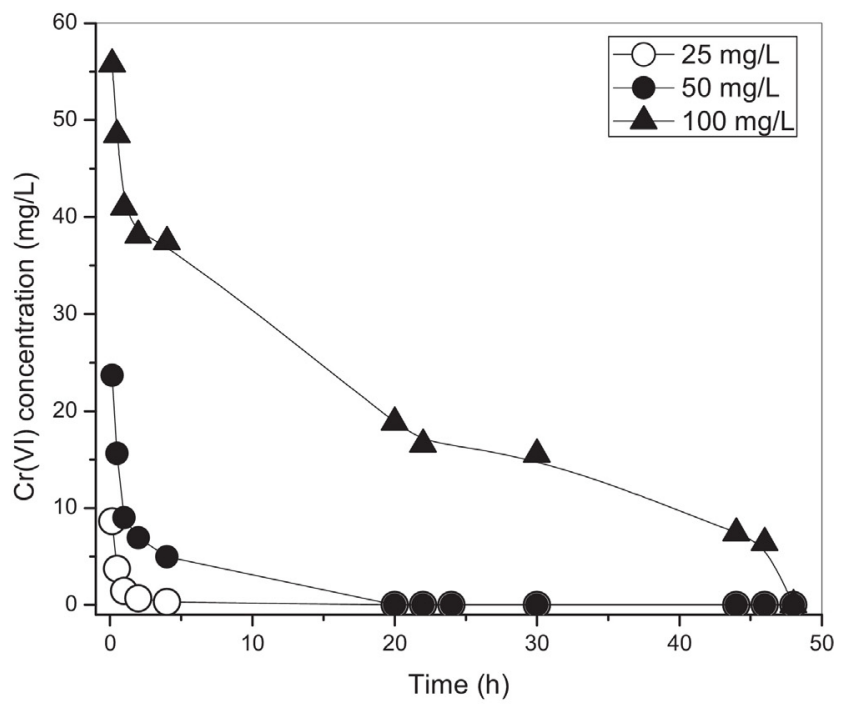

a)

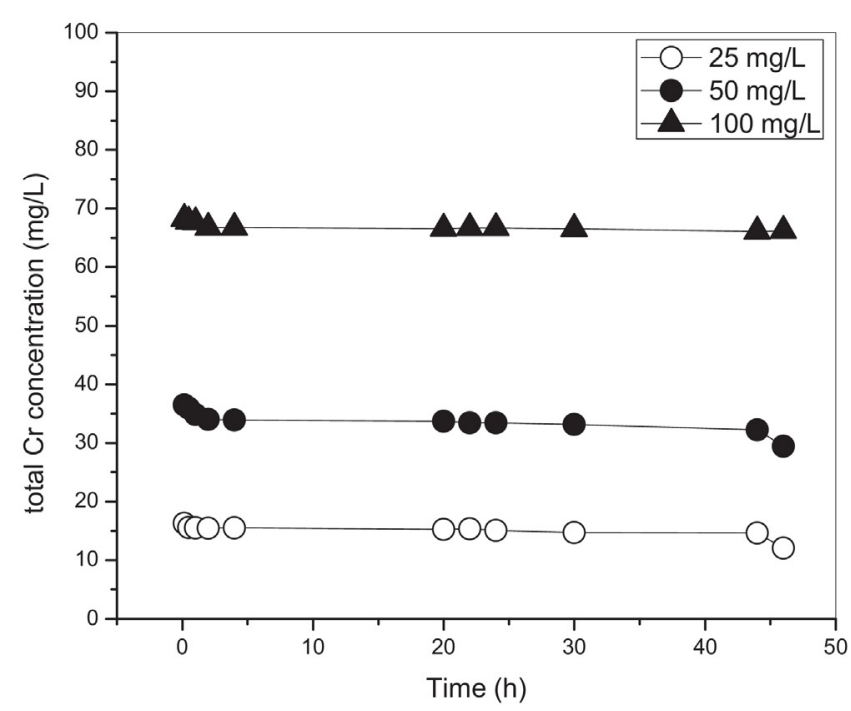

b)

Fig. 8 - (a) The effect of contact time on $\mathrm{Cr}(\mathrm{VI})$ reduction by living A. viscosus; (b) The effect of contact time on total $\mathrm{Cr}$ removal by living $A$. viscosus.

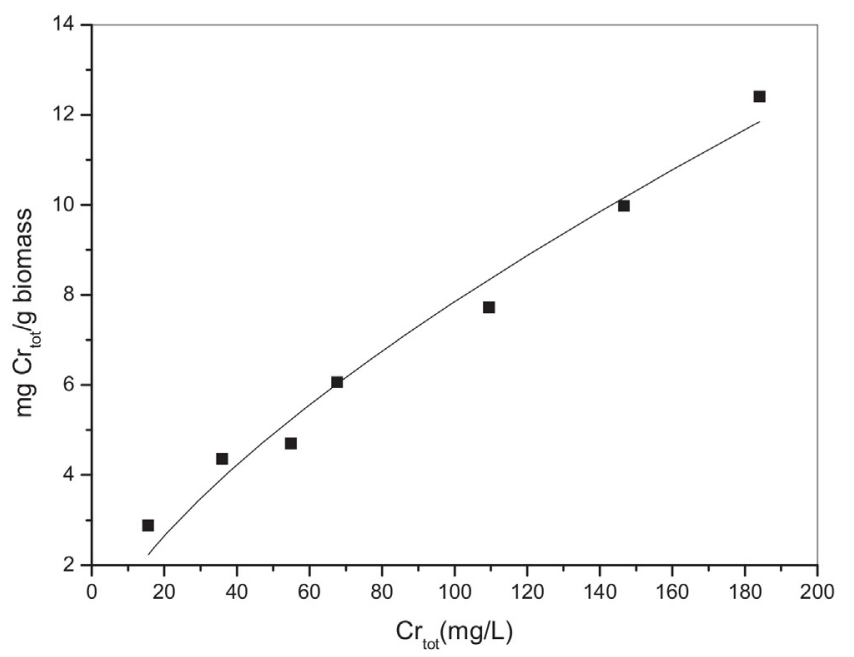

Fig. 9 - Isotherm plot of total $\mathrm{Cr}$ retention - Langmuir equation (living biomass dosage, $5 \mathrm{~g} / \mathrm{L}$ ).

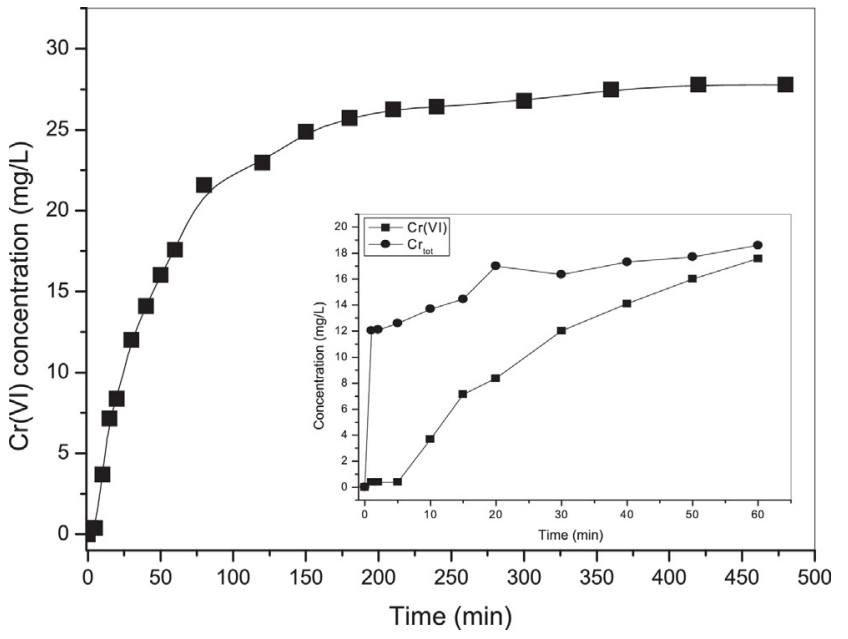

Fig. 10 - Breakthrough curves for $\mathrm{Cr}(\mathrm{VI})$ removal by $\mathrm{A}$. viscosus biofilm (initial $\mathrm{Cr}(\mathrm{VI})$ concentration: $25 \mathrm{mg} / \mathrm{L}$; $\mathrm{pH}$ 2; flow rate: $10 \mathrm{~mL} / \mathrm{min}$; temperature: $26^{\circ} \mathrm{C}$ ).

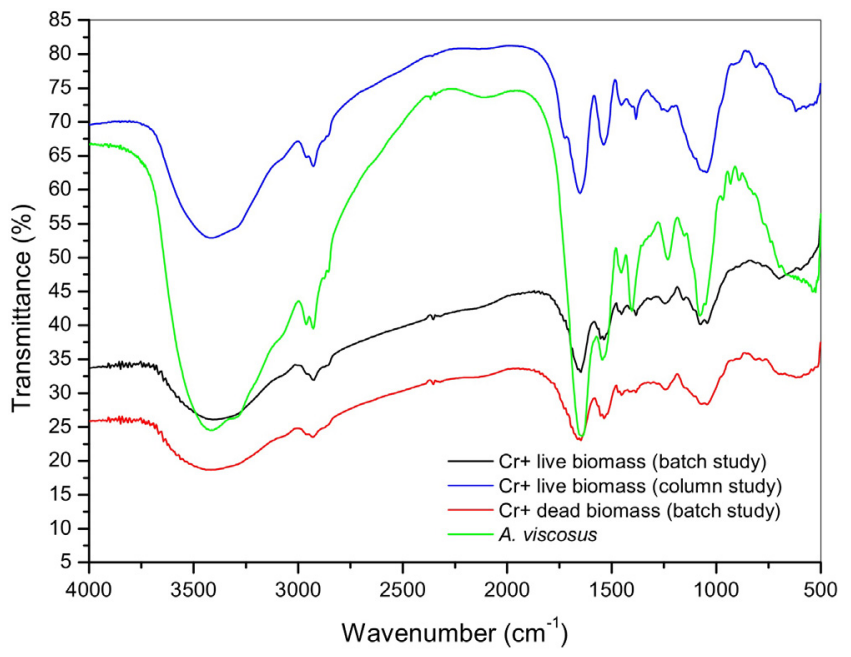

Fig. 11 - FTIR spectra of $A$. viscosus before and after chromium(VI) loading.

$\mathrm{Cr}(\mathrm{VI})$ removal is a complex phenomenon due to reduction of $\mathrm{Cr}$ (VI) to $\mathrm{Cr}$ (III). From the experimental results and FTIR analysis we can conclude that $\mathrm{Cr}(\mathrm{VI})$ can be directly reduced to $\mathrm{Cr}$ (III) in aqueous phase by contact with the electrondonor groups from the biomass. Electronic repulsion between positively charged functional groups and $\mathrm{Cr}$ (III) ions, release the $\mathrm{Cr}$ (III) in aqueous solution. The released $\mathrm{Cr}$ (III) in aqueous phase is bonded predominantly by the functional groups through an ion-exchange mechanism. Langmuir model fitting suggested the monolayer sorption of total $\mathrm{Cr}$ bound to the biomass.

\subsection{Comparison of dead and living A. viscosus in chromium removal}

The removal of $\mathrm{Cr}$ (VI) from aqueous solutions by dead and living biomass of $\mathrm{A}$. viscosus is a complex phenomenon based on reduction and adsorption mechanisms. Both living and dead cells of A. viscosus removed $\mathrm{Cr}(\mathrm{VI})$ under highly acidic $\mathrm{pH}$. These $\mathrm{pH}$ values represent an advantage due to the acidic nature of chromate - containing wastewaters. The work with dead biomass proved to be more suitable at high temperature. In the case of dead biomass, the process is endothermic, meaning that at high temperatures, high uptake values could 
be obtained (at $50^{\circ} \mathrm{C}, q_{\mathrm{Cr}_{\text {tot }}}^{\max }=1089.20 \mathrm{mg} / \mathrm{g}$ ), similar to those from living biomass analysis at $26^{\circ} \mathrm{C}\left(q_{\mathrm{Cr}}^{\max }=1161.3 \mathrm{mg} / \mathrm{g}\right)$ according to Langmuir isotherm modeling. Also, the positive thermodynamic parameters $\Delta S^{\circ}$ and $\Delta H^{\circ}$ indicated the process spontaneity at high temperatures for dead biomass. The uptake capacity of living and dead A. viscosus appears to be similar under optimum conditions established in the experiments, although the living biomass is able to completely reduce $\mathrm{Cr}$ (VI) to $\mathrm{Cr}$ (III) in fewer hours than the dead biomass (e.g. for $25 \mathrm{mg} / \mathrm{L}$ and $50 \mathrm{mg} / \mathrm{L}$ of initial $\mathrm{Cr}(\mathrm{VI})$ concentration, a complete reduction by living biomass was seen in $4 \mathrm{~h}$ and $20 \mathrm{~h}$ respectively, while $100 \%$ reduction in the case of $100 \mathrm{mg} / \mathrm{L} \mathrm{Cr}(\mathrm{VI})$ required $48 \mathrm{~h}$ of contact time; in the case of dead biomass, for an initial concentration of $25 \mathrm{mg} / \mathrm{L} \mathrm{Cr}(\mathrm{VI})$, it was observed that $\mathrm{Cr}(\mathrm{VI})$ was completely reduced to $\mathrm{Cr}(\mathrm{III})$ in $92 \mathrm{~h}$, for $50 \mathrm{mg} / \mathrm{L}$ initial concentration, $\mathrm{Cr}$ (VI) was completely reduced in $116 \mathrm{~h}$, while the complete removal of $100 \mathrm{mg} / \mathrm{L}$ of $\mathrm{Cr}(\mathrm{VI})$ required about $144 \mathrm{~h}$ of contact time). Meanwhile, experiments focusing on $\mathrm{Cr}(\mathrm{VI})$ removal by A. viscosus biofilm supported on polyethylene were also analyzed and showed a good uptake of chromium ions bound to the biomass $\left(q_{\mathrm{Cr}_{\text {tot }}}=\right.$ $20.37 \mathrm{mg} / \mathrm{g}$ ). The uptake capacity of the biofilm is higher than the uptake capacity obtained under optimum conditions in batch experiments $\left(q_{\mathrm{Cr}_{\text {tot }}}=12.4 \mathrm{mg} / \mathrm{g}\right)$. Taking into consideration the present findings, we can consider that both dead and living A. viscosus are effective biosorbents for removal and reduction of $\mathrm{Cr}(\mathrm{VI})$ from wastewaters under optimum conditions established in the experimental procedures.

\section{Conclusions}

Dead biomass as well as living biomass of A. viscosus proved to be promising biosorbents and may be used for $\mathrm{Cr}(\mathrm{VI})$ reduction to the less toxic $\mathrm{Cr}$ (III) from aqueous solution in highly acidic conditions. The solution $\mathrm{pH}$ has a strong influence on chromium biosorption and reduction. Both living and dead cells could successfully remove $\mathrm{Cr}$ (VI) from aqueous solution in highly acidic $\mathrm{pH}$ (pH 1 and 2) with an efficiency of $100 \%$ for $100 \mathrm{mg} / \mathrm{L}$ initial $\mathrm{Cr}(\mathrm{VI})$ concentration. The living A. viscosus proved its efficiency as biosorbent with respect to uptake values of total $\mathrm{Cr}$, as predicted by Langmuir model $1161.3 \mathrm{mg} / \mathrm{g}$ compared to $14.4 \mathrm{mg} / \mathrm{g}$ in the case of dead biomass, at $26^{\circ} \mathrm{C}$. The uptake values of living biomass obtained at room temperature $\left(26^{\circ} \mathrm{C}\right)$ were similar to the uptake values obtained in the case of dead biomass under high temperature conditions $\left(50^{\circ} \mathrm{C}\right)$. In addition to batch mode experiments, a column experiment was performed with the aim of removing $\mathrm{Cr}(\mathrm{VI})$ by an A. viscosus biofilm supported on a new type of polyethylene. The results obtained in this case showed a good uptake of chromium ions bound to the biomass, of $20.37 \mathrm{mg} / \mathrm{g}$.

In conclusion, A. viscosus biomass can be used to convert $\mathrm{Cr}(\mathrm{VI})$ to $\mathrm{Cr}$ (III) in batch and continuous modes with good results. Furthermore, the availability, low cost and low environmental impact makes this biomass an attractive option in treating wastewater polluted with chromium.

\section{Conflict of interest}

We declare no conflict of interest.

\section{Acknowledgements}

This paper was elaborated with the support of BRAIN project Doctoral scholarships as an investment in intelligence - ID 6681, financed by the European Social Found and Romanian Government and with the support of a grant of the Romanian National Authority for Scientific Research, CNCS - UEFISCDI, project number PN-II-ID-PCE-2011-3-0559, Contract 265/2011. H. Figueiredo is thankful to "FCT - Fundação para a Ciência e Tecnologia" for the financial support through the concession of PhD grant SFRH/BD/28201/2006.

\section{References}

Abskharon, R.N.N., Gad, El-Rab, S.M.F., Hassan, S.H.A., Shoreit, A.A.M., 2009. Reduction of toxic hexavalent chromium by E. coli. Global J. Biotechnol. Biochem. 4, 98-103.

Acevedo-Aguilar, F.J., Espino-Saldaña, A.E., Leon-Rodriguez, I.L., Rivera-Cano, M.E., Avila-Rodriguez, M., Wrobel, K., Lappe, P., Ulloa, M., Gutiérrez-Corona, J.F., 2006. Hexavalent chromium removal in vitro and from industrial wastes, using chromate-resistant strains of filamentous fungi indigenous to contaminated wastes. Can. J. Microbiol. 52, 809-815.

Altaher, H., Alghamdi, A., Omar, W., 2015. Innovative biosorbent for the removal of cadmium ions from wastewater. Environ. Eng. Manag. J. 14, 793-800.

Bai, R.S., Abraham, T.E., 2001. Biosorption of Cr (VI) from aqueous solution by Rhizopus nigricans. Bioresour. Technol. 79, 73-81.

Baral, A., Engelken, R.D., 2002. Chromium based regulations and greening in metal finishing industries in the USA. Environ. Sci. Policy 5, 121-133.

Baral, S.S., Das, S.N., Rath, P., 2006. Hexavalent chromium removal from aqueous solution by adsorption on treated sawdust. Biochem. Eng. J. 31, 216-222.

Cabatingan, L.K., Agapay, R.C., Rakels, J.L.L., Ottens, M., van der Wielen, L.A.M., 2001. Potential of biosorption for the recovery of chromate in industrial wastewaters. Ind. Eng. Chem. Res. 40, 2302-2309.

Chojnacka, K., 2010. Biosorption and bioaccumulation - the prospects for practical applications. Environ. Int. 36, 299-307.

Clesceri, L.S., Greenberg, A.E., Eaton, A.D., 2005. In: Franson, M.A.H. (Ed.), Standard Methods for the Examination of Water and Wastewater. , 20th edition. American Public Health Association, 1015 Fifteenth Street, NW, Washington, DC, pp. 20005-22605.

Donmez, G.C., Aksu, Z., Ozturk, A., Kutsal, T., 1999. A comparative study on heavy metal biosorption characteristics of some algae. Process Biochem. 34, 885-892.

Ebrahimi, A., Ehteshami, M., Dahrazma, B., 2015. Isotherm and kinetic studies for the biosorption of cadmium from aqueous solution by Alhaji maurorum seed. Process Saf. Environ. 98, 374-382.

Ertugay, N., Bayhan, Y.K., 2008. Biosorption of Cr(VI) from aqueous solution solutions by biomass of Agaricus bisporus. J. Hazard. Mater. 154, 432-439.

Fan, Q., Shao, D., Lu, Y., Wu, W., Wang, X., 2009. Effect of pH, ionic strength, temperature and humic substances on the sorption of $\mathrm{Ni}$ (II) to Na-attapulgite. Chem. Eng. J. 150, 188-195.

Figueiredo, H., Silva, B., Quintelas, C., Neves, I.C., Tavares, T., 2010. Effect of the supporting zeolite structure on $\mathrm{Cr}$ biosorption: performance of a single-step reactor and of a sequential batch reactor - a comparison study. Chem. Eng. J. 163, 22-27.

Flouty, R., 2015. Removal of $\mathrm{Pb}$ (II) and $\mathrm{Cu}$ (II) from aqueous solutions by Chlamydomonas reinhardtii: infrared and thermal analysis. Environ. Eng. Manag. J. 14, 871-877.

Fonseca, B., Pazos, M., Tavares, T., Sanromán, M.A., 2012. Removal of hexavalent chromium of contaminated soil by coupling electrokinetic remediation and permeable reactive biobarriers. Environ. Sci. Pollut. Res. 19, 1800-1808.

Gavrilescu, M., Demnerová, K., Aamand, J., Agathos, S., Fava, F., 2015. Emerging pollutants in the environment: present and future challenges in biomonitoring, ecological risks and bioremediation. New Biotechnol. 32, 147-156.

Ghosh, A., Das (Saha), P., Sinha, K., 2015. Optimization of reduction of copper using Stenotrophomonas maltophilia PD2 
biomass and artificial neural network modeling. Environ. Eng. Manag. J. 14, 37-44.

Hlihor, R.M., Diaconu, M., Fertu, D., Chelaru, C., Sandu, I., Tavares, T., Gavrilescu, M., 2013. Bioremediation of Cr(VI) polluted wastewaters by sorption on heat inactivated Saccharomyces cerevisiae biomass. Int. J. Environ. Res. 7, 581-594.

Hlihor, R.M., Bulgariu, L., Sobariu, D.L., Diaconu, M., Tavares, T., Gavrilescu, M., 2014. Recent advances in biosorption of heavy metals: support tools for biosorption equilibrium, kinetics and mechanism. Rev. Roum. Chim. 59, 527-538.

Hlihor, R.M., Diaconu, M., Leon, F., Curteanu, S., Tavares, T., Gavrilescu, M., 2015. Experimental analysis and mathematical prediction of Cd(II) removal by biosorption using support vector machines and genetic algorithms. New Biotechnol. 32, 358-368.

Ho, Y.S., 2006. Review of second-order models for adsorption systems. J. Hazard. Mater. 136, 681-689.

Jaafarzadeh, N., Teymouri, P., Akbar Babaei, A., Alavi, N., Ahmadi, M., 2014. Biosorption of cadmium (II) from aqueous solution by NaCl-treated Ceratophyllum demersum. Environ. Eng. Manag. J. 13, 763-773.

Khambhaty, Y., Mody, K., Basha, S., Jha, B., 2009. Kinetics, equilibrium and thermodynamic studies on biosorption of hexavalent chromium by dead fungal biomass of marine Aspergillus niger. Chem. Eng. J. 145, 489-495.

Kumar, R., Bishnoi, N.R., Bishnoi, G.K., 2008. Biosorption of chromium (VI) from aqueous solution and electroplating wastewater using fungal biomass. Chem. Eng. J. 135, 202-208.

Li, H., Lin, Y., Guan, W.G., Chang, J., Xu, L., Guo, J., Wei, G., 2010. Biosorption of $\mathrm{Zn}$ (II) by live and dead cells of Streptomyces ciscaucasicus strain CCNWHX 72-14. J. Hazard. Mater. 179, 151-159.

Liu, C.-C., Wang, M.-K., Chiou, C.-S., Li, Y.-S., Lin, Y.-A., Huang, S.S., 2006. Chromium removal and sorption mechanism from aqueous solutions by wine processing waste sludge. Ind. Eng. Chem. Res. 45, 8891-8899.

Liu, Y.X., Yuan, D.X., Yan, J.M., Li, Q.L., Ouyang, T., 2011. Electrochemical removal of chromium from aqueous solutions using electrodes of stainless steel nets coated with single wall carbon nanotubes. J. Hazard. Mater. 186, $473-480$.

Liu, C., Fiol, N., Villaescusa, I., Poch, J., 2016. New approach in modeling $\mathrm{Cr}$ (VI) sorption onto biomass from metal binary mixtures solutions. Sci. Total Environ. 541, 101-108.

Lopez-Nuñez, P.V., Aranda-García, E., Cristiani-Urbina, M.C., Morales-Barrera, L., Cristiani-Urbina, E., 2014. Removal of hexavalent and total chromium from aqueous solutions by plum (P. domestica L.) tree bark. Environ. Eng. Manag. J. 13, 1927-1938.

Loukidou, M.X., Zouboulis, A.I., Karapantsios, T.D., Matis, K.A., 2004. Equilibrium and kinetic modeling of chromium(VI) biosorption by Aeromonas caviae. Colloids Surf. A 242, 93-104.

Murphy, V., Hughes, H., McLoughlin, P., 2008. Comparative study of chromium biosorption by red, green and brown seaweed biomass. Chemosphere 70, 1128-1134.

Murugavelh, S., Mohanty, K., 2014. Mechanism of Cr(VI) bioaccumulation by Phanerochaete chrysosporium. Environ. Eng. Manag. J. 13, 281-287.

Nogueira, R., Alves, C., Matos, M., Brito, A.C., 2009. Synthesis and degradation of poly- $\beta$-hydroxybutyrate in a sequencing batch biofilm reactor. Bioresour. Technol. 100, 2106-2110.

Nourbakhsh, M., Sag̃, Y., Özer, D., Aksu, Z., Kutsal, T., Çağlar, A., 1994. A comparative study of various biosorbents for removal of chromium(VI) ions from industrial waste waters. Process Biochem. 29, 1-5.

Paduraru, C., Tofan, L., Teodosiu, C., Bunia, I., Tudorachi, N., Toma, O., 2015. Biosorption of zinc(II) on rapeseed waste: equilibrium studies and thermogravimetric investigations. Process Saf. Environ. 94, 18-28.

Park, D., Yun, Y.-S., Cho, H.Y., Park, J.M., 2004. Chromium biosorption by thermally treated biomass of the brown Seaweed, Ecklonia sp. Ind. Eng. Chem. Res. 43, 8226-8232.
Park, D., Yun, Y.-S., Jo, J.H., Park, J.M., 2005. Mechanism of hexavalent chromium removal by dead fungal biomass of Aspergillus niger. Water Res. 39, 533-540.

Park, D., Yun, Y.-S., Lee, D.S., Lim, S.-R., Park, J.M., 2006. Column study on $\mathrm{Cr}$ (VI)-reduction using the brown seaweed Ecklonia biomass. J. Hazard. Mater. B137, 1377-1384.

Park, D., Lim, S.R., Yun, Y.S., Park, J.M., 2007. Reliable evidences that the removal mechanism of hexavalent chromium by natural biomaterials is adsorption-coupled reduction. Chemosphere 70, 298-305.

Park, D., Yun, Y.-S., Kim, J.Y., Park, J.M., 2008. How to study Cr(VI) biosorption: use of fermentation waste for detoxifying $\mathrm{Cr}(\mathrm{VI})$ in aqueous solution. Chem. Eng. J. 136, 173-179.

Parvathi, K., Nagendran, R., 2007. Biosorption of chromium from effluent generated in chrome-electroplating unit using Saccharomyces cerevisiae. Separ. Sci. Technol. 42, 625-638.

Pei, Q.H., Shahir, S., Raj Santhana, A.S., Zakaria, Z.A., Ahmad, W.A., 2009. Chromium(VI) resistance and removal by Acinetobacter haemolyticus. World J. Microbiol. Biotechnol. 25, 1085-1093.

Prabhakaran, S.K., Vijayaraghavan, K., Balasubramanian, R., 2009. Removal of $\mathrm{Cr}(\mathrm{VI})$ ions by spent tea and coffee dust: reduction to $\mathrm{Cr}$ (III) and biosorption. Ind. Eng. Chem. Res. 48, 2113-2117.

Rosca, M., Hlihor, R.M., Cozma, P., Comăniţă, E.-D., Simion, I.M., Gavrilescu, M., 2015. Potential of biosorption and bioaccumulation processes for heavy metals removal in bioreactors. In: E-Health and Bioengineering Conference (EHB), pp. 1-4, http://dx.doi.org/10.1109/EHB.2015.7391487, ISBN: 978-1-4673-7544-3.

Quintelas, C., Fernandes, B., Castro, J., Figueiredo, H., Tavares, T., 2008a. Biosorption of $\mathrm{Cr}$ (VI) by three different bacterial species supported on granular activated carbon - a comparative study. J. Hazard. Mater. 153, 799-809.

Quintelas, C., Fernandes, B., Castro, J., Figueiredo, H., Tavares, T., 2008b. Biosorption of $\mathrm{Cr}$ (VI) by a Bacillus coagulans biofilm supported on granular activated carbon (GAC). Chem. Eng. J. 136, 195-203.

Quintelas, C., Fonseca, B., Silva, B., Figueiredo, H., Tavares, T., 2009. Treatment of chromium(VI) solutions in a pilot-scale bioreactor through a biofilm of Arthrobacter viscosus supported on GAC. Bioresour. Technol. 100, 220-226.

Samuel, M.S., Evy, A.A.M., Chidambaram, R., 2015. Isotherm modelling, kinetic study and optimization of batch parameters using response surface methodology for effective removal of $\mathrm{Cr}$ (VI) using fungal biomass. PLoS ONE 10, e0116884, http://dx.doi.org/10.1371/journal.pone.0116884.

Silva, B., Figueiredo, H., Neves, I.C., Tavares, T., 2009. The role of $\mathrm{pH}$ on $\mathrm{Cr}(\mathrm{VI})$ reduction and removal by Arthrobacter viscosus. Int. J. Chem. Biol. Eng. 2, 100-103.

Singh, K.K., Rastogi, R., Hasan, S.H., 2005. Removal of Cr(VI) from wastewater using rice bran. J. Colloid Interface Sci. 290, 61-68.

Ungureanu, G., Santos, S., Boaventura, R., Botelho, C., 2015. Biosorption of antimony by brown algae S. muticum and A. nodosum. Environ. Eng. Manag. J. 14, 455-463.

Vijayaraghavan, K., Jegan, J., Palanivelu, K., Velan, M., 2005. Batch and column removal of copper from aqueous solution using a brown marine alga Turbinaria ornate. Chem. Eng. J. 106, 177-184.

Vijayaraghavan, K., Yun, Y.-S., 2008. Bacterial biosorbents and biosorption. Biotechnol. Adv. 26, 266-291.

Wang, X.S., Li, Z.Z., Sun, C., 2008. Removal of $\mathrm{Cr}$ (VI) from aqueous solutions by low-cost biosorbents: marine macroalgae and agricultural by-products. J. Hazard. Mater. 153, 1176-1184.

Wu, J., Zhang, H., He, P.-J., Yao, Q., Shao, L.-M., 2010. Cr(VI) removal from aqueous solution by dried activated sludge biomass. J. Hazard. Mater. 176, 697-703.

Xu, L., Luo, M., Li, W., Wei, X., Xie, K., Liu, L., Jiang, C., Liu, H., 2011. Reduction of hexavalent chromium by Pannonibacter phragmitetus LSSE-09 stimulated with external electron donors under alkaline conditions. J. Hazard. Mater. 185, 1169-1176. 
Yang, K., Zhang, J., Yang, T., Wang, H., 2016. Investigation of equilibrium and kinetics of $\mathrm{Cr}(\mathrm{VI})$ adsorption by dried Bacillus cereus using response surface methodology. Water Sci. Technol. 73, 617-627.
Zhang, H., Liu, L., Chang, Q., Wang, H., Yang, K., 2015. Biosorption of $\mathrm{Cr}$ (VI) ions from aqueous solutions by a newly isolated Bosea sp. strain Zer-1 from soil samples of a refuse processing plant. Can. J. Microbiol. 61, 399-408. 